\title{
Attepe - Elmadağ-Menteş-Karaçat Demir Sahalarında Yüzey Suyu-Yeraltı Suyu İlişkisinin Araştırılması
}

\author{
Investigation of Surface Water-Groundwater Interaction \\ in Attepe - Elmadag-Mentes - Karacat Iron Fields \\ Muhterem DEMİROĞLU ${ }^{1} \mathbb{D}$, Yüksel ÖRGÜN² $\mathbb{D}$ \\ ${ }^{1}$ Hakkari Üniversitesi Mühendislik Fakültesi İnşaat Müh. Bölümü, Hakkari \\ ${ }^{2}$ İTÜ Maden Fakültesi Jeoloji Mühendisliği Bölümü, Maslak-İstanbul
}

Öz

Çalışmada, Seyhan nehri ana havzasında yer alan Menteş havzası ve yakın çevresinde bulunan, AttepeElmada ğ-Menteş-Karaçat demir sahalarında yüzey ve yeraltı suları arasındaki ilişki incelenmiştir. İnceleme alanında Prekambiryen-Ordovisiyen yaş aralığında düşük dereceli metamorfizma geçirmiş metakarbonat ve metakırıntılılar ve bunları açılı uyumsuzlukla örten Miyosen konglomeralar ve güncel alüvyonlar yüzeylemektedir. Havzanın da içinde yer aldığı bölgede, tektonik hareketlerin etkisiyle aşırı kırıklı, çatlaklı ve yer yer ileri düzeyde karstik yapı kazanmış olan metakarbonatlar ana akifer olarak belirlenmiştir. Menteş deresi karstik akiferin doğal yeraltı suyu boşalım güzergahını ve aynı zamanda aktif güncel karstlaşmanın erozyon seviyesini oluşturmaktadır. Faylar, havzadaki geçirimsiz olan diğer birimlerin yanal ve düşey konumlarını belirleyerek, karstik akiferin sürekliliğini engellemiştir. Alansal olarak yağışlarla, yanı sıra Menteş deresinden büyük miktarda noktasal olarak beslenen yeraltı sularının, sığ dolaşımlı ve akiferle temas süresi kısa, 5-10 yıllık genç sular olduğu ortaya konmuştur. Menteş deresi ortalama debisi doğu alt havzası çıkışında $474 \mathrm{~L} /$ sn olarak hesaplanmıştır. Debi ölçümleri Menteş deresinden, kurak ve yağışlı devrelerde sırasıyla yaklaşık 150 ve $1000 \mathrm{~L} /$ sn suyun, yeraltı suyuna ilave olduğunu göstermiştir. Yeraltı maden ocağının da yer aldığı Karaçat akiferinin yan havzalardan ziyade Menteş deresinden beslendiği belirlenmiştir. Hidrojeolojik değerlendirmeler ve izotop analiz sonuçları önceki çalışmalarda da belirlenen Attepe gölü ile Karaçat akiferi arasında hidrolik bir ilişkinin olmadığ değerlendirmesi teyit etmiştir.

Anahtar kelimeler: Yüzey suları, Yeraltı suları, Yeraltı suyu-yerüstü suyu ilişkisi, Akifer, Karst

\begin{abstract}
In this study, surface waters and groundwater interactions were investigated at the Attepe-Elmadağ-MenteşKaraçat iron fields. The study area takes place in the Menteş upper watershed and the nearby surroundings, which is located in the Seyhan River main basin. The study area is composed of the metamorphic metacarbonates and metaclastics, which were subjected to low grade metamorphism in the Precambrian-Ordovician age range. Miocene conglomerates and current alluviums overlie them with angular unconformity. In the region where the basin is located, the metacarbonates (recrystallized limestone and dolomites) which are highly fractured, cracked and in some places have dominantly karstic structure, have been identified as the main aquifer. The Mentes Stream forms the natural groundwater discharge route and the erosion level of karstification of the aquifer. The faults prevent the continuity of the karstic aquifer by determining the lateral and vertical positions of other impermeable units. It
\end{abstract}


Demiroğlu, Örgün

has been shown that groundwater, recharged with diffuse infiltration by precipitation and a large amount of point infiltration from the Menteş creek, is shallow circulated young water with a short residence time of 5-10 years. It is determined that a large part of the Mentes Creek (150-1000 L/s at dry and wet seasons, respectively) disappeared and added to the Karaçat aquifer. The average flow rate of the Mentess stream was calculated as $474 \mathrm{~L} / \mathrm{s}$ at the eastern lower basin exit. The Karaçat aquifer, which also includes Karaçat underground mine quarry, is recharged from the Menteş Creek rather than neighboring basins. Hydrogeological investigations and isotope data confirmed the previous work result that there is no flow relation between Attepe lake and Karaçat aquifer.

Keywords: Surface water, Groundwater, Aquifer, Karst, Surface water and groundwater interaction

\section{GíRiş}

Yeraltı suyu, beslenme alanlarından tahliye alanlarına, değişen uzunluklardaki akış yolları boyunca hareket eder ve akarsu, göl ve sulak alan gibi farklı tür yüzey suyu ile etkileşim halindedir. Ancak, etkileşimlerin gözlemlenmesi ve ölçülmesi zordur. Akış yolları akiferin türüne bağlı olarak, onlarca, yüzlerce hatta binlerce metre uzunluğunda olabilir; Beslenim ve boşalım arasındaki zaman ise birkaç günden birkaç yıla, binlerce yıla kadar değişebilir. Yakında bulunan bir rezervuar kaynağın tahliyesi, şiddetli yağışlar, hızlı kar erimesi gibi etkenler akış yönünü ve zamanını çok kısa zaman dilimlerinde değiştirebilir. Ayrıca insan faaliyetleri, yeraltı suyu ve yüzey suyu arasındaki etkileşimi hızlıca değiştirebilir.

Kireçtaşı ve dolomitlerin yaygın yüzey alanına sahip olduğu Menteş havzasının en önemli özelliği, Mansurlu demir madenleri olarak adlandırılan ve Attepe-Elmadağ-MenteşKaraçat ocakları başta olmak üzere, onlarca yıldır yüzey ve yeraltı madencilik yöntemleriyle işletilen birçok demir sahasına sahip olmasıdır. Sahanın bir diğer özelliği ise yeraltı suyunun doğal akım yönü, beslenim ve boşalma koşullarında değişime neden olan yeraltı maden ocağ1 (Karaçat galerisi) ve bu galeride biriken suyu Menteş Deresine boşaltmak için yapılan yaklaşık $1 \mathrm{~km}$ uzunluğunda bir drenaj galerisinin varlığıdır. Zengin yeraltı suyu potansiyeline sahip olduğu anlaşılan havzada, madencilik faaliyeti biten Attepe maden sahasında oluşan Attepe gölü ve dört mevsim su taşıyan Menteş deresi önemli yüzey suyu kaynaklarını temsil etmektedir.

Ülkemizin önemli demir yataklarının bulunduğu bölgenin jeolojik ve mineralojik özelliklerine ve maden yataklarına yönelik yapılmış çok sayıda çalışma olup, bunların kapsaml1 listesi Tiringa (2009) ve Eken (2012)'de verilmiştir. 1950 li yıllardan beri yüzey ve yeraltı demir cevheri üretimi yapılan havzanın da içinde yer aldığ 1 bölgenin hidrolojik, hidrojeolojik ve hidrojeokimyasal özelliklerini tanımlamaya yönelik sınırlı sayıda çalışma, Demiroğlu ve Örgün (2016) yayınında genel olarak tanıtılmıştır. Menteş Havzası hidrojeolojisi ilk defa Demiroğlu ve Örgün (2016) tarafindan çalışılmış; Menteş Deresi Üst Havzada yer alan birimler yerel zengin, zayıf ve çok zayıf akiferler olarak sınıflandırılmış, hazırlanan hidrojeoloji haritasında sunulmuş ve suların hidrojeokimyasal özellikleri belirlenmiştir.

Yeraltı suyu, madencilik faaliyetlerinde en önemlirisk faktörünü oluşturmaktadır. Türkiye'de 2011 yılında Afşin-Elbistan (Kahramanmaraş) kömür madeninde ve 2014 y1lında Ermenek (Karaman) kömür madeninde meydana gelen ve can ve mal kayıplarına neden olan ani yeraltı suyu boşalımı, yeraltı suyunun seviyesi, dağılımı ve miktarının bilinmesinin, madenciliğin güvenli yapılabilmesi için ne kadar önemli olduğunu 
ortaya koymuştur. Yeraltı suları ile ilgili bir diğer önemli konu da gözlemlenmesi ve ölçülmesi zor olan yüzey suları ile etkileşimidir.

$\mathrm{Bu}$ çalışmada, Yahyalı (Kayseri) ilçesi sınırları içinde yer alan Menteş deresi doğu alt havzasında bulunan, Elmadağ-Menteș-Karaçat demir sahalarında yeraltısuları ve yüzey suları arasındaki ilişki incelenmiştir. Bu amaca yönelik gözlem kuyuları açılmış, basınçlı su testleri, Menteş deresinde ve drenaj galerisi çıkışında debi ölçümleri, hidrolojik hesaplamalar, su kimyası analizleri ve izotop analizleri yapılmıştır. Ayrıca Seyhan nehri ana havzasinda yer alan bölgede, yüzey suyu Menteş deresi ve Attepe gölü ile temsil edilmektedir. Karaçat sahasında yeraltı madenciliği yapmak amaciyla açılan Karaçat galerisinde üretim sırasında boşalan ve kontrol edilemeyen suyun, Attepe baraj gölünde biriken su ile bağlantılı olmadığını belirleyen Demiroğlu ve Örgün (2016)'nın sonuçları yeni veriler 1şığında tekrar değerlendirilmiştir.

\section{ÇALIŞMA ALANI}

\section{Genel Özellikler}

Çalışma alanı, Seyhan nehri ana drenaj alanı içinde kalan Menteş havzasında yer alır (1/25 000 ölçekli Kayseri L35-d3,d4 ve Kozan M35-a1,a2 topoğrafik paftaları). Kayseri ili Yahyalı ilçesi sınırlarında kalan Menteş havzasının KD-GB sınırının şistlerle kesildiğinin belirlenmesinden sonra çalışma alanı, üretim yapılan ocakları da içerecek şekilde, Menteş deresi doğu alt havzası adı altında drenaj kanalı çıkış bölgesiyle sınırlandırılmış ve havza alanı $27.7 \mathrm{~km}^{2}$ olarak belirlenmiştir (Şekil 1). Belirlenen alanda demir cevheri üretimi yapılan Karaçat sahasında yüzey ve yeraltı madenciliği yapılmaktadır. Elmadağ ve Menteş ocaklarında ve havza sınırının güneyinde kalan Attepe maden ocağında üretim yapılmamaktadır. Yoğun madencilik faaliyetlerinin yanı sıra Karaçat yeraltı maden ocağında biriken suyu Menteş deresine boşaltan yaklaşı $1 \mathrm{~km}$ uzunluğundaki drenaj galerisi ve terkedilmiş Attepe maden sahasında oluşmuş Attepe gölünün varlığı havzanın diğer önemli özellikleridir.

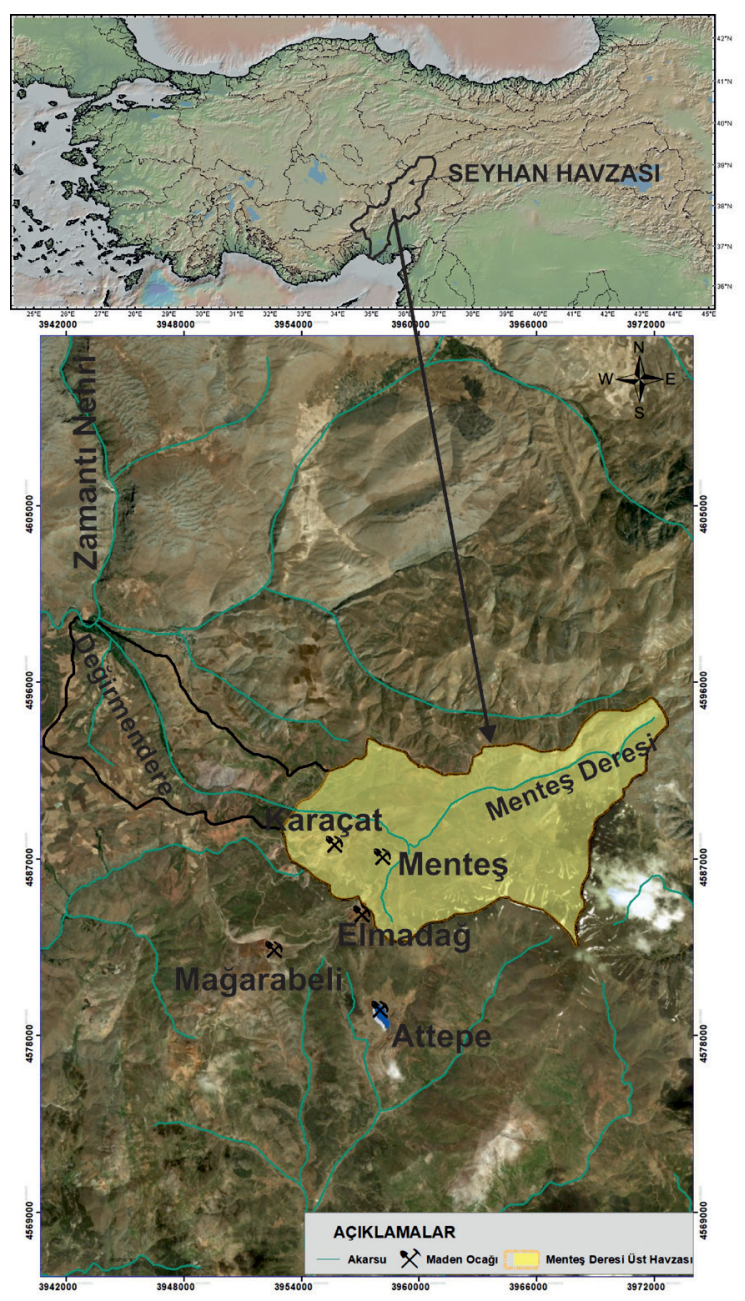

Şekil 1. İnceleme alanı yer bulduru haritası.

Figure 1. Location map of the study area.

Akdeniz iklimi ile karasal iklimin arasında "Geçiş İklimi” özelliğinde, yarı karasal iklim şartlarına sahip bölgede yazları sıcak ve kurak, 
Demiroğlu, Örgün

kışları ise soğuk ve kar yağışlı geçer. Seyhan Havzası içinde bir alt havza olan Menteş havzasında, Zamantı ve Göksu Nehirleri birleşerek Seyhan Nehrini oluşturmaktadır. Alp orojenik kuşağı içinde yer alması nedeniyle, tektonik hareketlerden ileri derecede etkilenmiş olan bölgede engebeli bir morfoloji hâkimdir. Akarsu yönünden zengin olan bölgede yüksek debili birçok kaynak mevcuttur. Menteş Deresi kuzey doğuda $2100 \mathrm{~m}$ ve $2150 \mathrm{~m}$ kotlarından boşalan kaynaklarla başlamakta, daha sonra Değirmendere adını alarak Zamantı Nehrine boşalmaktadır. Çalışma alanı içindeki kaynaklardan $1675 \mathrm{~m}$ ve $1685 \mathrm{~m}$ kotlarından boşalan Uyuz pınarı ve Karaköy’ün içme suyu kaynakları kuzeybatıya doğru Menteş deresine boşalmaktadır. 1730 m-1740 m kotlarından boşalan Avlağa kaynağı ve Şantiye suyu kaynağı ise Menteş deresi drenaj alanı dışındadır (Şekil 2).

\section{Jeolojik ve Hidrojeolojik Özellikler}

Çalışma alanında PrekambriyenOrdovisiyen yaş aralığında düşük dereceli metamorfizma geçirmiş metakarbonat ve metakırıntılilar ve metatortul birimler, Üst Kretase yaşlı ofiyolitik kayaçlar ve bunları açılı uyumsuzlukla örten Miyosen yaşı ıçökeller yüzeylemektedir. MTA 1/25000 ölçekli bölgenin jeoloji haritası, Arda vd. (2008) ve Demiroğlu ve Örgün (2016) çalışmalarından yararlanılarak hazırlanan çalışma alanının jeoloji haritası Şekil 2'de verilmiştir. Çalışma alanında PrekambiryenOrdovisiyen dönemini temsil eden birimler, ağırlıkla metakırıntılılardan oluşan Emirgazi formasyonu, kuvarsitlerden oluşan Zabuk formasyonu, dolomit ve kireçtaşlarından oluşan Değirmentaş formasyonu ve meta şeyl, killi şistler, meta siltten oluşan Armutludere formasyonudur. Çalışma sahasının güney batısında yüzeyleyen
Üst Kretase yaşlı melanj niteliğindeki Bozkır birliği asidik tüf ve bazik- ultrabazik kayaçlardan oluşur. Konglomera ve marn ardalanmasından oluşan Miyosen yaşlı seri, tüm birimlerin üzerinde açısal uyumsuzlukla yer alır. Bölgenin genel jeolojik yapısı ve maden yatakları hakkında çok sayıda araştırmacı çalışmış olup bunlardan bazıları şunlardır: Lucias (1927), Blumenthal (1941), Rondot (1956), Gürkan (1966), Arikan (1968), Özgül (1971, 1976), Özgül ve Kozlu (2002), Ayhan ve İplikçi (1978), Şahin ve Bakırdağ (1984), Şahin vd. (1985), Ayhan (1988), Küpeli (1991, 1998), Alan vd. (2007), Dayan (2007), Arda vd. (2008), Tiringa, (2009) ve Tringa vd. (2009). Sahadaki en genç birim akarsu yataklarında ve yatakların çevrelerinde biriken alüvyonlar ve yaklaşık 70 yıllık maden atıklarından oluşan moloz yığınlarıdır. Menteş havzası ve yakın çevresinde ana akifer olarak tanımlanan Değirmentaş formasyonu çalışma alanında kuvarsitler üzerine killi seviyelerle başlar ve uyumlu olarak üste doğru dolomitdolomitik kireçtaşlarıyla devam ederek kristalize kireçtaşlarıyla sona erer. Birim içinde yapılan sondajda 349 m kireçtaşı kesilmiş; sondaj aynı birim içinde sonlandırılmıştır (Demiroğlu ve Örgün, 2016).

Bölge jeolojik yapı ve konumunu, Üst Kratese sonunda, Alp orojenezinin Laramiyen fazıyla ilgili sıkıştırma hareketlerinin etkisiyle oluştuğu düşünülen tektonik hareketlerle kazanmıştır. Şiddetli tektonik hareketler sonucunda gelişen faylar, sahadaki birimlerin yanal ve düşey konumlarını belirleyerek, karstik akiferin sürekliliğini engellemiştir. Fay hatları Attepe maden kazı alanından, Karaçat maden ocağ1 ve Menteş deresine kadar uzanmaktadır. Çalışma kapsamında oluşturulan inceleme alanının fay haritası Şekil 3'de verilmiştir. 


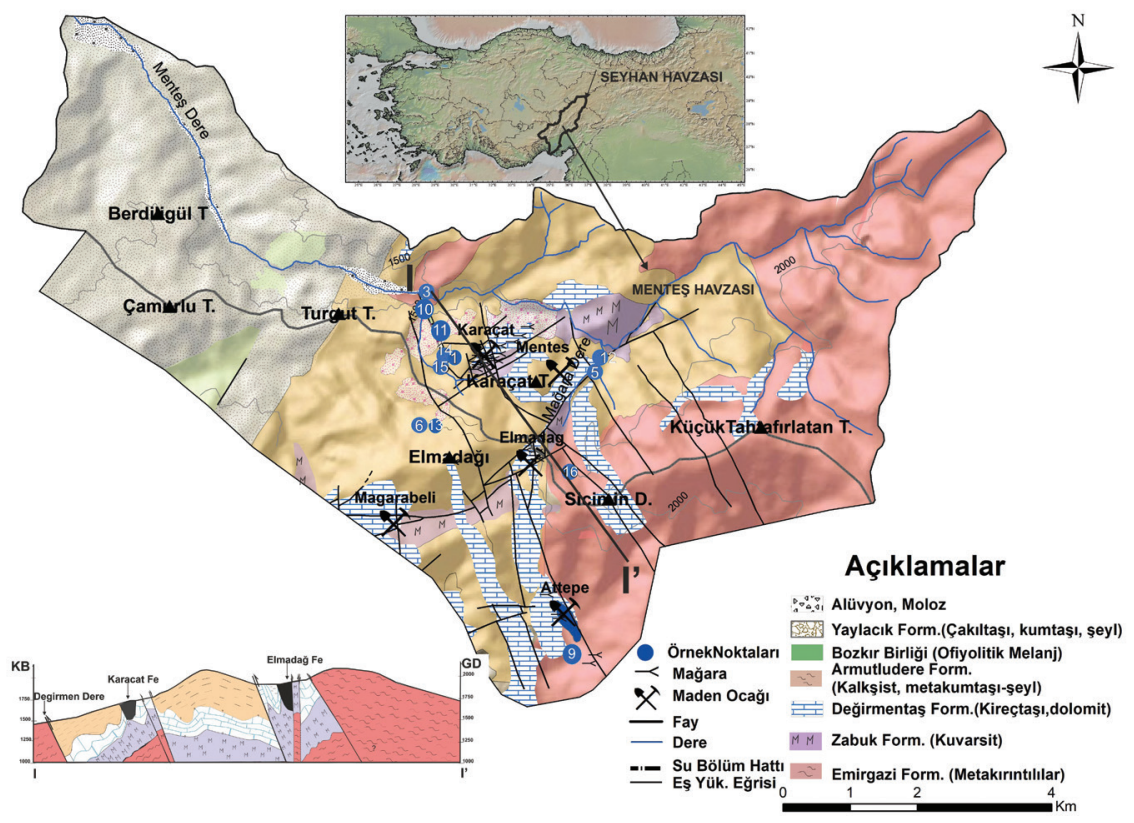

Şekil 2. Çalışma alanının jeoloji haritası (MTA 1/25000 ölçekli bölgenin jeoloji haritası, Demiroğlu ve Örgün, 2016; Arda vd., 2008' den revize edilmiştir).

Figure 2. Geological map of the study area (MTA 1/25000 scale, revised after Demiroglu and Orgun, 2016; Arda et al., 2008).

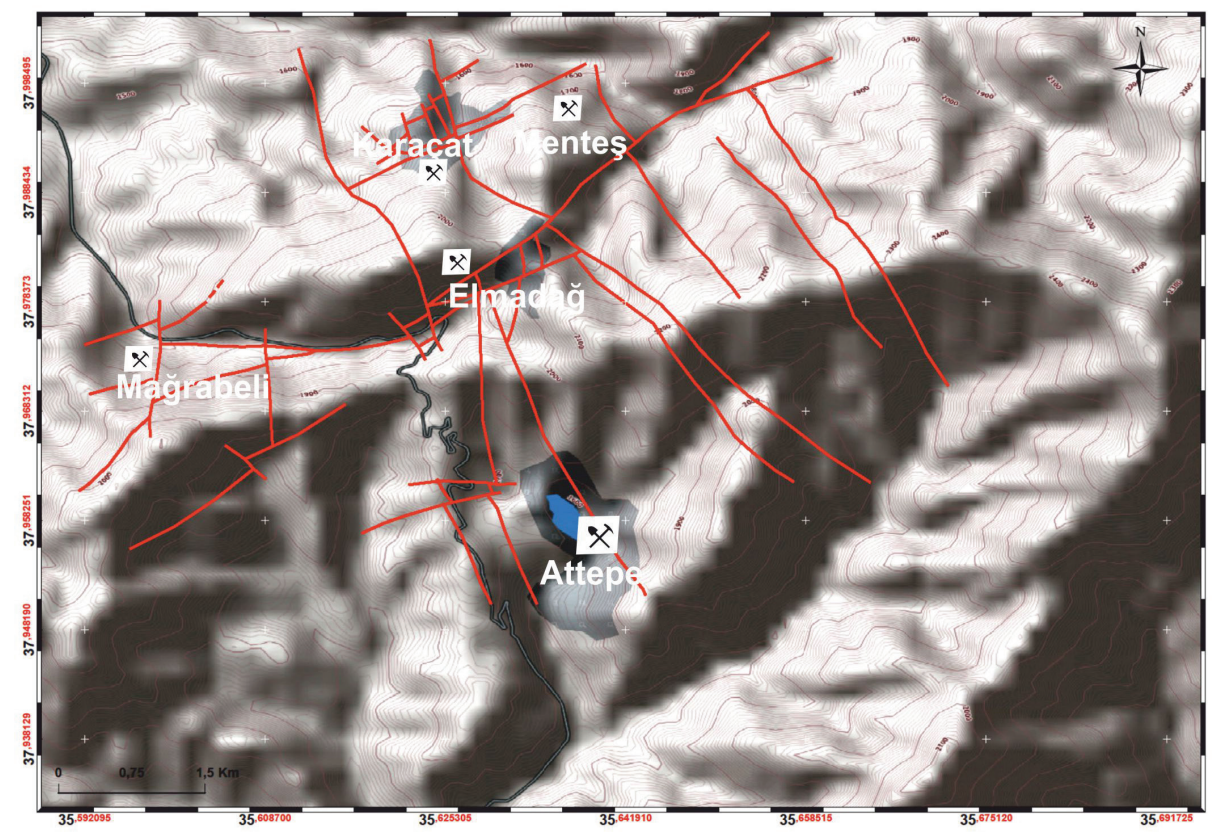

Şekil 3. İnceleme alanı fay haritası.

Figure 3. Fault map of the study area. 
Demiroğlu, Örgün

Bölgede D-B yönlü sıkışmaların sonucu devrik ve yatık kıvrımlar ve yataya yakın büyük bindirmeler meydana gelmiştir. Bölgede kimi yerlerde kilometrelerce izlenebilen düşük eğimli tektonik düzlemler boyunca Prekambriyen yaşta Emirgazi Formasyonu, Ordovisiyen yaşlı Armutludere Formasyonunu üzerlemiştir. Çalışma alanında, Miyosen yaşlı çökelleri de etkileyen, KKD-GGB eksen gidişli antiklinal ve senklinaller gelişmiştir (Özgül ve Kozlu, 2002; Arda vd., 2008). Yapılan arazi çalışmalarında, sahada Eosen ve Miyosen sonu sıkışmalı tektonizma sonucu KD-GB doğrultulu bindirme faylarının geliştiği saptanmıştır (Mağarabeli, Karaçat, Kızıl ve Mağaradere fayları gibi). KDGB doğrultulu sol yanal ve KB-GD uzanımlı sağ yanal doğrultu atımlı bu faylar, önemli ölçüde eğim atım bileşenine de sahip olup, eşlenik konumda Geç Kratese 'de gelişen bindirme fay dokanaklarını ve Eosende gelişen bindirme faylarını kesmektedir. Önemli demir cevherleri de bu kesişim zonlarında tanımlanmıştır (Attepe ve Elmadağbeli yatakları gibi). Sahadaki KDGB uzanımlı sol yanal doğrultu atımlı en genç faylar ise, hem tüm fay sistemlerini hem de demir cevherleşmelerini kesmektedir. Geç Miyosenden itibaren geliştiği düşünülen bu faylar tamamen doğrultu atım karakterinde olup, yersel eğim atım bileşenine de sahiptir (Arda vd., 2008). Geç Kratese' de geliştiği düşünülen bindirme fay zonu kataklastikleri Karaçat ve Menteş akiferi arasında bariyer oluşturmuştur. Tüm bu tektonik olaylar sonucunda karbonatlı birimlerin aşırı kırıklıçatlaklı bir yapı kazanmış olması yeraltı sularının dolaşıp depolanmasının yanı sıra bölgedeki demir cevherlerinin oluşumunda ve yataklanmasında da birinci derecede etkili olmuştur. Menteş havzası ve yakın çevresinde 10 dan fazla maden yatağı ve maden zuhuru tanımlanmıştır (Tiringa, 2009; Eken, 2012). Dolomitleri ve kireçtaşlarını geçmişte etkilemiş, günümüzde de devam eden karstik süreçler çalışma alanında birçok mağara ve dolin meydana gelmesine neden olmuştur. Bölgede Alp orojenik kuşağ 1 içinde yer alması nedeniyle, tektonik hareketlerden ileri derecede etkilenmiştir. Üst Kretase'den itibaren Miyosen dönemine kadar etkili olan sıkışmalı tektonizma sonucu, başta karbonatlı birimler olmak üzere bölgedeki kayaçların kazandığı aşırı kırıklı-çatlaklı yapı bölgenin iklim koşullarıyla buluşunca, bölge yerel zengin yeraltı suyu kaynaklarına sahip olmuştur. Değirmentaş Formasyonunun dolomit-dolomitik kireçtaşları, kireçtaşları ve kristalize kireçtaşları, tektonizma ve Tersiyer başlarından itibaren etkili olmaya başlayan karstlaşma süreçleri ile verimi iyi akifer özelliği kazanmıştır.

Havzada şist ve kuvarsitler ile sınırlanan Değirmentaş Formasyonu ana akifer niteliğindedir; şistlerin akifer ortam özelliği zayıf su taşımaz olup, bünyelerindeki kırık ve çatlaklar boyunca hareket eden su ile sınırlıdır. Elmadağ ve civarında, yüksek kotlarda, Armutludere şistlerinin aşınmasıyla yüzeyleyen karbonatlar da havzanın besleniminde önemli rol oynamaktadır. Bünyesinde birçok mağara ve dolin barındırmakta olan kristalize kireçtaşı ve dolomitlerde, Karaçat ocağ1 ve Attepe ocağ1 civarlarında 50 metre derinliğe ulaşan karstik boşluklar tespit edilmiştir (Demiroğlu ve Örgün, 2016). Çalışma alanında yeraltı sularının besleniminin, kar ve yağmur şeklindeki yağışlardan alansal olarak, Menteş deresinden ise noktasal olarak gerçekleştiği bu çalışma ile belirlenmiştir. Yeraltı sularının Menteş deresine doğru olan ana akım yönü, derenin alt kotunda, $1407 \mathrm{~m}$, açılan drenaj galerisi faaliyete geçtikten sonra drenaj galerisine doğru değişmiştir. Çalışma sahasında dolomit-dolomitik kireçtaşları ve kristalize kireçtaşları yerel zengin akiferler, kuvarsitler ve Armutludere şistleri zayıf akiferler, Emirgazi metakırıntılıları ise çok zayıf akiferler olarak sınıflandırılmıştır. Bu çalışma kapsamında hazırlanan Menteş üst havzasının hidrojeoloji haritası Şekil 4'de verilmiştir. 


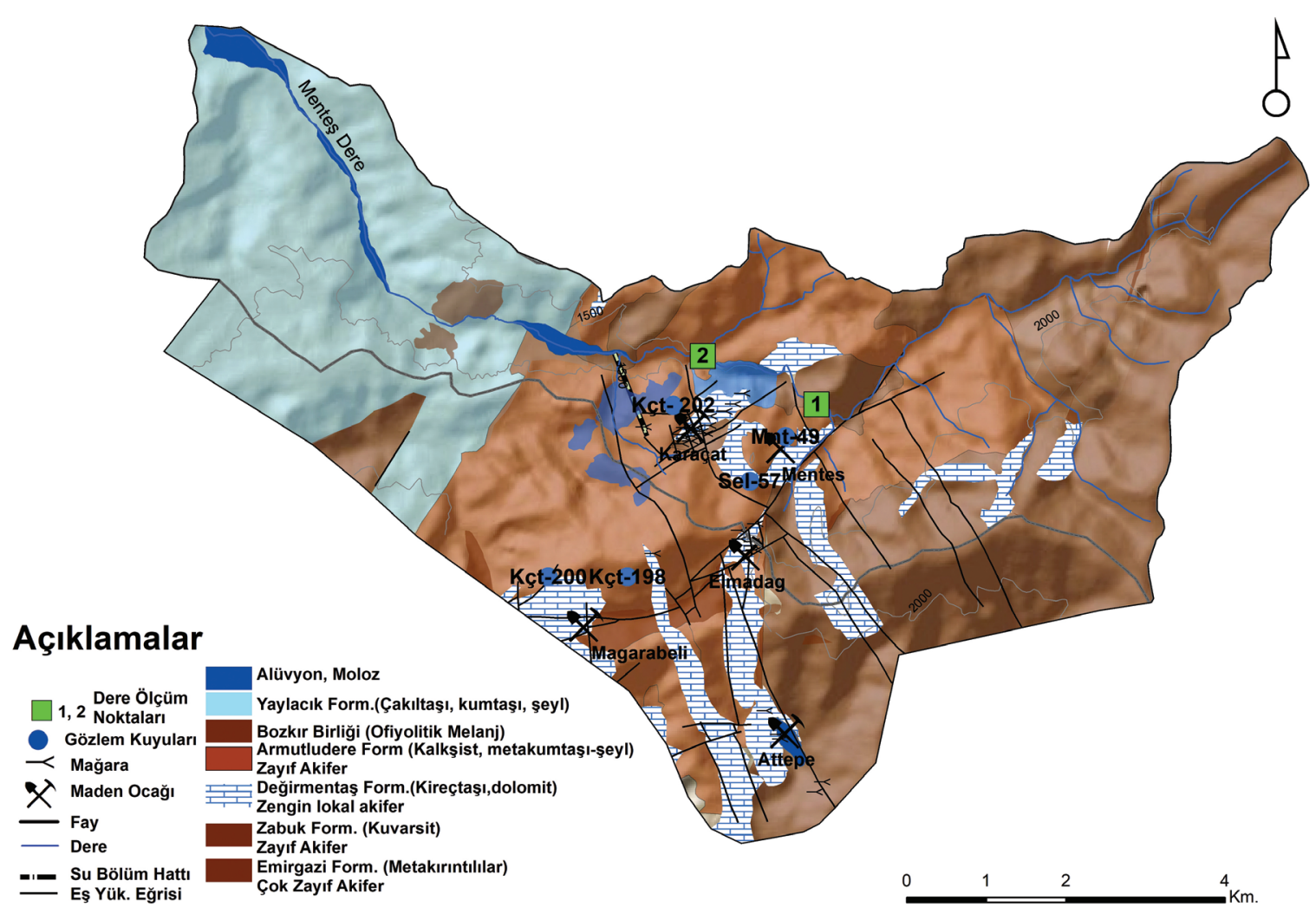

Şekil 4. İnceleme alanı hidrojeoloji haritası ve civarında açılan gözlem kuyuları (Kçt-200, Kçt-202, vb.).

Figure 4. Hydrogeological map of the study area and observation wells opened in the close vicinity (Kçt-200, Kçt202, etc.).

\section{YÖNTEM}

Elmadağ-Menteş-Karaçat demir sahalarını da içine alan yaklaşı $27.7 \mathrm{~km}^{2}$ drenaj alanına sahip Menteş deresi doğu alt havzasında yeraltı suları ile Menteş deresi ve Attepe gölü arasındaki ilişki araştırılmıştır. Çalışmalarda Demiroğlu ve Örgün (2016) tarafindan hazırlanan harita ve şekillerden yararlanılmıştır. Yeraltı ve yüzey suları arasındaki ilişkiyi araştırmak için hidrolojik hesaplamalar, yeraltı su seviyesi (YSS), debi ölçümleri, basınçlı su testleri, su kimyası analizleri ve izotop analizleri yapılmıştır.
Menteş deresi drenaj alanı içinde yeraltı suyu beslenim koşullarının belirlenmesi için inceleme alanına yakın Devlet Meteoroloji İşleri (DMİ) ve Devlet Su İşleri (DSİ) Genel Müdürlüklerine ait yağış istasyonlarının verileri kullanılmıştır.

Demiroğlu ve Örgün (2016) çalışmasında da yer verilen su noktalarından 12 noktada tekrar yerinde ölçümler yapılmış, bu noktalardan sekizinden tekrar yağışlı ve kurak dönemi temsilen örnekler alınarak kimyasal analizleri (ana iyon ve iz elementler) ve izotop analizleri $\left(\delta^{18} \mathrm{O}, \delta^{2} \mathrm{H}\right.$ ve -Trityum) yapılmıştır. Proje bütçesi kapsamında bazı örnekler analiz 
Demiroğlu, Örgün

sonuçlarının kontrolü amaçlı çift alınıp, farklı numaralandırılarak, laboratuvarlara gönderilmiştir. Yerinde ölçüm yapılan su noktaları ve ölçüm sonuçları Çizelge 4'de verilmiştir. Bu noktalar Şekil 2'de gösterilmiştir. Sularının sicaklık (T), pH, Eh, Elektriksel iletkenlik (EC), $\mathrm{NaCl}$ (Tuzluluk) ve toplam alkalinite parametreleri yerinde ölçülmüştür. Ölçümlerden önce cihazlar, bu cihazlar için hazırlanmış çözeltiler ile kalibre edilmiştir. pH ve Eh değerleri "Crison PH 25 model" EC ve Tuzluluk $(\mathrm{NaCl})$ değerleri ise "Crison CM 35 model” cihazlarla ölçülmüştür. Anyon, katyon, iz element, $\delta^{18} \mathrm{O}, \delta^{2} \mathrm{H}$ ve $\delta^{3} \mathrm{H}$ analizleri için örnek alma sirasında, USEP standart prosedürü takip edilmiştir. Buna göre her bir örnek kab1 3 kez çalkalanmış, sular filtrelenmiştir (0.45 $\mu \mathrm{m}$ millipore); katyon ve iz element analizleri için alınan örneklere $\mathrm{pH}<2.0$ olacak şekilde $\% 2 \mathrm{HNO}_{3}(\mathrm{v} / \mathrm{v})$ eklenmiştir. Örneklerin tümü laboratuvara gönderilinceye kadar $4^{\circ} \mathrm{C}$ 'de saklanmıştır. Anyon analizleri İzmir Yüksek Teknoloji Enstitüsü Çevre Geliştirme Uygulama ve Araştırma Merkezi Laboratuvarlarında İyon Kromatografi(IC) yöntemiyleyapılmıştır. Katyon ve iz element analizleri ACME laboratuvarında STD TMDA-70 standards'a göre ICP-MS (PerkinElmer SCIEX-ELAN 9000) cihaziyla yapılmıştır. İzotop analizleri ise DSİ İzotop Laboratuvarında (Ankara) yapılmıştır. Analiz edilen parametrelerin hata oranlarını görmek için örneklerde tekrarlı analizler gerçekleştirilmiş olup, hata oranın $\% 0-<\% 2$ arasında değişmiştir.

Uzun gözlem, inceleme, ölçme ve hidrojeokimyasal verilerden yararlanarak belirlenen 5 noktada gözlem kuyuları açılmış ve basınçlı su deneyleri gerçekleştirilmiştir (Şekil 4). Karaçat galerisinde biriken yeraltı suyunu drene etmek amaciyla kullanılan drenaj galerisinden boşalan suyun yaklaşık 2 yıl süreyle aylık debi ölçümleri yapılmıştır.
Elde edilen veriler; saha gözlem ve incelemeleriyle birlikte değerlendirilerek AttepeElmadağ-Menteş-Karaçat demir sahalarında yeraltı suları ve yüzey suları arasındaki ilişki açıklanmaya çalışılmıştır.

\section{BULGULAR}

\section{Hidroloji}

Yaklaşık $49 \mathrm{~km}^{2}$ yüzey alanına sahip Menteş deresi drenaj alanı içinde kalan çalışma alanında yarı karasal iklim şartları hâkim olup, bölgede morfoloji son derece engebelidir. Yerel zengin yeraltı su potansiyeline ve düşük debili birçok kaynağa sahip bölgede yeraltı sularının beslenmesi yağmur ve kar şeklindeki yağışlarla olmaktadır. Yağışlar kışları çoğunlukla kar şeklindedir; özellikle yüksek kotlarda yağışların kar şeklinde olması akiferlerin beslenmesi açısından önemlidir. Havzada en önemli akarsu kuzey doğuda $2100 \mathrm{~m}$ ve $2150 \mathrm{~m}$ kotlarından boşalan kaynaklarla başlayan, daha sonra Değirmendere adını alarak Zamantı Nehrine boşalan Menteş deresidir.

Sahada yıllık ortalama yağış miktarı 25,5 milyon $\mathrm{m}^{3}$ dür ve bunun 4,3 milyon $\mathrm{m}^{3} / \mathrm{y} 1 \mathrm{l}^{1}$ yeraltına sızmaktadır (Demiroğlu ve Örgün, 2016). Ancak maden sahalarında yeraltı sularını deşarj etmek için yapılan ve 2014 yılında devreye alınan drenaj galerisinden deşarj başladıktan sonra yapılan ölçümler, yeraltı suyu potansiyelinin daha yüksek olduğunu göstermiştir. Demiroğlu ve Örgün, (2016) tarafından trityum analizleriyle yeraltı sularının genç sular olduğunun anlaşılmasıyla yağ yeniden değerlendirilmiştir. Seyhan Havzası içinde yer alan DSİ yağış istasyonu verileri temin edilerek Thiessen yağış poligonları oluşturulmuş ve ortalama yıllık toplam yağış değeri $985 \mathrm{~mm}$ olarak hesaplanmıştır. Hesaplamada D18M012- 
Hasançavuşlar ve D18M019-Çeralan DSI meteoroloji gözlem istasyonlarının ortalama yıllık toplam yağış verileri kullanılmıştır. Menteş havzasının KD-GB sınırının şistlerle kesildiğinin belirlenmesiyle çalışma alanı Menteş havzası drenaj kanalı çıkış bölgesiyle sınırlandırılmış ve yaklaşık $27.7 \mathrm{~km}^{2}$ yüzey alanına sahip havza "Menteş deresi doğu alt havzası" olarak adlandırılmıştır.

$\begin{array}{crrr}\text { Coğrafi } & \text { Bilgi } & \text { Sistemleri } & \text { (CBS) } \\ \text { yazılımlarında } & \text { havza } & \text { karakteristiklerini }\end{array}$ hesaplamak için havzanın Sayısal Yükseklik Modeli (SYM) gerekmektedir. Bu veri https:// gdex.cr.usgs.gov/gdex/ web adresinden $30 \mathrm{~m}$ yatay ve düşey çözünürlükte elde edilmiş ve alt havzada ana akarsu eğimi 0.0853 olarak hesaplanmıştır. Menteş deresi üzerinde herhangi bir akım gözlem istasyonu olmadığı için debisi çevre istasyon verilerinden faydalanılarak hesaplanmıştır. Seyhan havzasında Zamantı Nehri üzerinde, Göksu Nehri ile birleştiği kısma kadar olan bölgede DSİ ve Elektrik İşleri Etüt İdaresi'ne (EİEI) ait 34 adet akım gözlem istasyonu (AGI) belirlenmiştir. Bu istasyonlardan en az 10 y1l kesintisiz, eksiksiz ve müdahalesiz (baraj, gölet vs. yapılmadan önceki) verisi olan istasyonlar ele alınmıştır. Menteş deresi doğu alt havzası çıkışındaki ortalama debiyi tahmin etmek için eşitlik (1) çoklu regresyon yöntemiyle SPSS ve Minitab istatistik yazılımlarında elde edilmiștir:

$\mathrm{Q}=\mathrm{C} \times(\mathrm{A} \times \mathrm{P})^{\mathrm{m}}$

$\mathrm{Q}=\mathrm{C} \times(\mathrm{A} \times \mathrm{P})^{\mathrm{m}} \times\left(\mathrm{S}_{0}\right)^{\mathrm{n}}$

Burada Q havza çıkışındaki ortalama debiyi $\left(\mathrm{m}^{3} / \mathrm{s}\right)$, A yağ 1 ş alanını $\left(\mathrm{km}^{2}\right)$, P yıllık ortalama yağışı $(\mathrm{mm}) \mathrm{S}_{0}$ ana yatak eğimini, $\mathrm{C}$, $m$ ve $n$ değerleri de katsayıları ifade etmektedir
(Temelsu Mühendislik Limited Şirketi, 1988; Burgan ve Aksoy, 2018 ).

Çalışma sırasında öncelikle debi ile alan ve yağış ilişkisi çoklu regresyon yöntemiyle $\mathrm{Q}=0.101952 \times(\mathrm{A} \times \mathrm{P})^{0.21995} \quad$ denklemi elde edilmiş ve elde edilen denkleme göre Menteş deresi doğu alt havzası çıkışında ortalama debi $0.964 \mathrm{~m}^{3} / \mathrm{s}$ yani yaklaşı $1 \mathrm{~m}^{3} / \mathrm{s}$ olarak hesaplanmıştır. Kalibrasyon değerleri daha yüksek olmasına karşın validasyon için dere ölçümleri dikkate alınarak eğim değişkeni ilave edilmiştir. Zamantı Nehri havzasında bulunan yan kollardaki dereler üzerinde bulunan 11 adet AGI için CBS yazılımları yardımıyla ana yatak eğimleri hesaplanmış (Çizelge 1) ve istatistik yazılımlarından aşağıdaki denklem (3) elde edilmiştir:

$\mathrm{Q}=0.00175898 \times(\mathrm{A} \times \mathrm{P})^{0.250291}\left(\mathrm{~S}_{0}\right)^{-1.23523}$

Denklemin çıkarılması için kullanılan AGİ'lerin yağış alanları 9.9-173.7 km² arasında değişmektedir. Elde edilen denkleme göre Menteş Deresi Doğu Althavzası çıkışında ortalama debi $0.474 \mathrm{~m}^{3} / \mathrm{s}$, yani yaklaşı $500 \mathrm{~L} /$ sn olarak hesaplanmıştır. Bu değer uzun yıllar ortalaması olarak düşünülmelidir.

$\mathrm{Q}=0.00175898 \times(\mathrm{A} \times \mathrm{P})^{0.250291} \times\left(\mathrm{S}_{0}\right)^{-1.2352}$

$\mathrm{A}=27.7 \mathrm{~km}^{2}$

$\mathrm{P}=985.05 \mathrm{~mm}$

$\mathrm{S}_{0}=0.085$

$\mathrm{C}=0.00175898$

$\mathrm{m}=0.250291$

$\mathrm{n}=-1.23523$

$\mathrm{Q}=\mathrm{C} \times(\mathrm{A} \times \mathrm{P})^{\mathrm{m}} \times\left(\mathrm{S}_{0}\right)^{\mathrm{n}}=0.474 \mathrm{~m}^{3} / \mathrm{s}$. 
Demiroğlu, Örgün

Çizelge 1. Denklem için kullanılan akım gözlem istasyonlarının hesaplanan havza karakteristikleri.

Table 1. Calculated basin characteristics of the current observation stations used for the equation.

\begin{tabular}{lllllll}
\hline Sıra no & İstasyon no & İstasyon adı & $\begin{array}{l}\text { Yağış alanı } \\
\left(\mathbf{k m}^{2}\right)\end{array}$ & $\begin{array}{l}\text { Ortalama } \\
\text { yıllık toplam } \\
\text { yağış }(\mathbf{m m})\end{array}$ & $\begin{array}{l}\text { Akarsu ana } \\
\text { yatak eğimi }\end{array}$ & $\mathbf{Q}_{\text {ort }}\left(\mathbf{m}^{3} / \mathbf{s n}\right)$ \\
\hline 1 & D18A008 & Tacin & 9.9 & 423.7 & 0.0686 & \\
\hline 2 & D18A009 & Örencik & 36 & 403.8 & 0.0693 & 0.350 \\
\hline 3 & D18A010 & Yeniköy & 26.9 & 963.8 & 0.0687 & 0.887 \\
\hline 4 & D18A018 & Hasançavuşlar & 136 & 1006.3 & 0.0364 & 2.261 \\
\hline 5 & D18A024 & Çamlıca & 173.7 & 1006.3 & 0.0655 & 0.573 \\
\hline 6 & D18A041 & Karacaören & 15.5 & 269.7 & 0.0422 & 0.068 \\
\hline 7 & D18A053 & Yahyali & 119.5 & 1006.3 & 0.0782 & 0.273 \\
\hline 8 & E18A016 & Yukarkaragöz & 137.2 & 423.7 & 0.0352 & 2.404 \\
\hline 9 & E18A032 & Büyükgümüşgün & 166.3 & 423.7 & 0.0297 & 1.724 \\
\hline 10 & E18A037 & Şamadan Beli & 32.3 & 924.8 & 0.1278 & 0.712 \\
\hline 11 & E18A039 & Çataloluk & 103.2 & 963.8 & 0.0513 & 1.486 \\
\hline
\end{tabular}

İleriki bölümlerde belirtilmiş olduğu gibi, Menteş deresi yüzeysel ve yüzey altı akışının karstik boşluklar ve faylar vasıtasıyla yeraltı suyuna doğrudan eklendiği dere üzerinde yapılan ölçümlerle tespit edilmiştir. Menteş deresinde atık sahası öncesi ve sonrasinda üç kere debi ölçümü yapılmıştır (Şekil 4). Menteş deresinde 06.07.2016 tarihinde yapılan ölçümde atık sahasının akış yukarısında 324 L/ sn olan Menteş deresi debisini, atık sahasını geçerken hızla azaldığı görülmüş olup, atık sahasının akış aşağısında ise yapılan ölçümde dere akımının $45 \mathrm{~L} / \mathrm{sn}$ olduğu belirlenmiştir. 05/02/2017 tarihinde ise fark $1050 \mathrm{~L} / \mathrm{sn}$ olarak ölçülmüştür. Yani kurak devrede 250 L/sn olan su kaybı yağışlı devrede $1000 \mathrm{~L} / \mathrm{sn}$ ye ulaşmaktadır. 19.06.2018 tarihinde atık sahası öncesinde $195 \mathrm{~L} / \mathrm{sn}$ olan debi sonrasında $20 \mathrm{~L} /$ sn ölçülmüştür. Menteş deresinde ölçülen akım değerleri değerlendirildiğinde dere suyundaki kaybın \%90 civarında olduğu görülmektedir. Karaçat yeraltı maden işletmesinde, yeraltı üretim faaliyetlerine devam edebilmek için açılan ve 1407-1418 kotlarını birleştiren drenaj galerisi ile yeraltı suyu seviyesi 1500 metreden 1418 metreye düşürülmüştür. Ancak yağ1şl1 dönemlerde bu seviye yükselmektedir. Drenaj galerisinin tamamlanıp devreye alındığ 2014 yılı yağışlı devresinde KÇT-176 No'lu gözlem kuyusunda $1438 \mathrm{~m}$ olarak ölçülen en yüksek yeraltı suyu seviyesi 2015 y1linda 1435m, 2016 y1lında 1433m, 2017 yağışlı devre sonunda 1426m ölçülmüştür.

\section{Yeraltı Suyu Seviye Ölçümleri}

Çalışma alanında yeraltı suyu seviyesi, açılan altı adet gözlem kuyusu vasitasıyla belirlenmeye çalışılmıştır. Ayrıca sahadaki maden arama temel sondajlarında, sondaj bitiminde de YSS ölçümleri yapılmıştır. Karaçat sahasında birçok temel sondaj kuyusunda YSS ölçülememiştir. Gözlem kuyularından KÇT-202 ve MNT-49 no'lu kuyularda kaydedilen seviye 
değişim değerleri Çizelge 2 ve Çizelge 3'de ayrı ayrı verilmiştir. Karaçat akiferi sınırları içinde yer alan KÇT-202 no'lu gözlem kuyusu seviye ölçümleri incelendiğinde, kuyuda 2018 y1lı yağışlı devrede seviyenin 28.92 metre yükseldiği görülecektir. Bu kuyuda kurak devre sonunda (12/10/2017) 263.97m olan su seviye başlangıcı 8/4/2018 tarihinde 235.05m olarak ölçülmüştür (Çizelge 2). Menteş akiferinde açılan MNT-49 no'lu gözlem kuyusunda kurak ve yağ $1 s ̧ l 1$ devrede suyun başlangıç seviyesi dar bir aralıkta değişmiş olup, değişim aralığı 199.62m (08/04/2018) ile 202.50m (10/11/2017) olarak kaydedilmiştir (Çizelge 3). KÇT-176 no'lu gözlem kuyusunda YSS seviyesi, 2015 yılı yağışlı devre sonunda $1435.87 \mathrm{~m}$ iken 2016 y1lında $1433.38 \mathrm{~m}$ olarak ölçülmüştür. Aynı tarihlerde diğer gözlem kuyularında su seviyeleri $1426.48 \mathrm{~m}$ ile 1427.7 $\mathrm{m}$ arasında değişmiştir. YSS ölçümeleri, bölgede sistemin daha çok GD yönünden beslendiğini ve bu yönde ani yükselimleri sağlayan gelişmiş karstik yapıların yüzeysuları ile ilişkili olduğunu göstermektedir.

Çizelge 2. KÇT-202 no'lu gözlem kuyusu YSS değişimleri.

Table 2. GWL changes in the observation well of KÇT-202.

\begin{tabular}{lllll}
\hline Tarih & Saat & $\begin{array}{l}\text { Kuyu } \\
\text { başlangıç } \\
\text { kotu }(\mathbf{m})\end{array}$ & $\begin{array}{l}\text { Suyun } \\
\text { başladığı } \\
\text { seviye } \\
(\mathbf{m})\end{array}$ & $\begin{array}{l}\text { Suyun } \\
\text { başladığı } \\
\text { kot }(\mathbf{m})\end{array}$ \\
\hline 13.07 .2017 & $14: 00$ & 1688.52 & 257.20 & 1431.32 \\
\hline 17.07 .2017 & $17: 00$ & 1688.52 & 258.00 & 1430.52 \\
\hline 24.08 .2017 & $10: 00$ & 1688.52 & 261.70 & 1426.82 \\
\hline 31.07 .2017 & $10: 00$ & 1688.52 & 262.35 & 1424.17 \\
\hline 24.09 .2017 & $18: 00$ & 1688.52 & 263.70 & 1424.82 \\
\hline 12.10 .2017 & $15: 00$ & 1688.52 & 263.97 & 1427.55 \\
\hline 10.11 .2017 & $15: 00$ & 1688.52 & 261.45 & 1427.07 \\
\hline 08.04 .2018 & $14: 00$ & 1688.52 & 235.05 & 1453.47 \\
\hline
\end{tabular}

Çizelge 3. MNT-49 no'lu gözlem kuyusu YSS değişimleri.

Table 3. Observation MNT-49 well GWL changes.

\begin{tabular}{lllll}
\hline Tarih & Saat & $\begin{array}{l}\text { Kuyu } \\
\text { başlangıç } \\
\text { kotu (m) }\end{array}$ & $\begin{array}{l}\text { Suyun } \\
\text { başladığı } \\
\text { seviye }(\mathbf{m})\end{array}$ & $\begin{array}{l}\text { Suyun } \\
\text { başladığı } \\
\text { kot }(\mathbf{m})\end{array}$ \\
\hline 21.05 .2017 & $10: 00$ & 1873.78 & 200.72 & 1673.06 \\
\hline 26.05 .2017 & $10: 00$ & 1873.78 & 200.31 & 1673.47 \\
\hline 27.05 .2017 & $10: 00$ & 1873.78 & 200.42 & 1673.36 \\
\hline 29.05 .2017 & $10:$ oo & 1873.78 & 200.59 & 1673.19 \\
\hline 04.06 .2017 & $10: 00$ & 1873.78 & 200.90 & 1672.88 \\
\hline 10.06 .2017 & $10: 00$ & 1873.78 & 201.60 & 1672.18 \\
\hline 17.06 .2017 & $14: 00$ & 1873.78 & 201.24 & 1672.54 \\
\hline 04.07 .2017 & $11: 00$ & 1873.78 & 201.60 & 1672.18 \\
\hline 31.08 .2017 & $10: 00$ & 1873.78 & 202.28 & 1671.50 \\
\hline 24.09 .2017 & $18: 00$ & 1873.78 & 202.70 & 1671.08 \\
\hline 12.10 .2017 & $15: 00$ & 1873.78 & 202.43 & 1671.35 \\
\hline 10.11 .2017 & $15: 00$ & 1873.78 & 202.50 & 1671.28 \\
\hline 08.04 .2018 & $12: 00$ & 1873.78 & 199.62 & 1674.16 \\
\hline
\end{tabular}

\section{Basınçlı Su Testleri}

Uzun gözlem, inceleme, ölçme ve hidrojeokimyasal verilerden yararlanarak seçilen 5 noktada açılan gözlem kuyularında basınçlı su deneyleri gerçekleştirilmiştir (Şekil 4). Basınçlı su testleri, kuyularda pabuçlarla kapatılan bir bölgeye farklı basınçlarda su vererek kaybolan veya emilen suyun miktarını belirlemek esasına dayanır; ölçülen su miktarı Lugeon değeri olarak ifade edilir. Lugeon birimi (LU); 10 $\mathrm{kg} / \mathrm{cm}^{2}$ lik basınç altında 1 dakikada 1 metre uzunluğundaki deney zonundan litre olarak kaçan suyun miktarıdır. Bu kuyularda yapılan basınçlı su testlerinde elde edilen sonuçlardan, şistler ve kuvarsitlerin geçirimsiz olduğu değerlendirilmiştir. Kireçtaşı ve dolomitlerin kalınlığının 350 metreye ulaştığ 1 alanlarda, tabanda yer alan dolomitik kireçtaşlarının Lugeon değerleri 1 den küçük bulunmuştur. Çalışma alanında gelişmiş karstlaşmanın 
Demiroğlu, Örgün

gözlenmediği zonlarda ise 5 Lugeondan küçük değerler ölçülmüştür. $\mathrm{Bu}$ değerler, arazinin bu kesimlerinde karstik boşluk ve kanallardan ziyade çatlak ve kırıklı bir yapının egemen olduğunu gösterebilir. Yüksek kotlarda 1950m - 1870m arasındaki 80 metrelik bölümde tanımlanan karstlaşma (Gözlem Kuyu no: Sel 57), diğer kuyularda faylanmalara bağl1 olarak daha düşük kotlarda gözlenmiştir. Fay hatlarının Attepe maden sahasından, Karaçat maden ocağ 1 ve Menteş deresine kadar uzandiğ 1 arazide rahatlıkla takip edilmektedir (bakınız Şekil 3).

\section{Hidrojeokimya}

Havzada yüzey ve yeraltı suyu ilişkisi araştırmasında, yeraltı suyu seviye ölçüm verileri, basınçlı su testleri, debi ölçümleri, hidrolojik hesaplamalarından elde edilen verileri, hidrojeokimyasal verilerle de desteklemek amaciyla seçilen su noktasında yerinde ölçümler yapılmış, alınan örnekler üzerinde ana, iz element ve izotop analizler yapılmıştır.

$\mathrm{Su}$ noktalarında arazide-yerli yerinde ve farklı tarihlerde ölçülen $\mathrm{T}, \mathrm{pH}, \mathrm{Eh}, \mathrm{EC}, \mathrm{NaCl}$ (Tuzluluk) ve toplam alkalinite değerleri Çizelge 4'te verilmiştir; Çizelgede 2014 yılına ait verilerin bir kısmı Demiroğlu ve Örgün, (2016)'dan alınmıştır. Çizelgeden görüldügüü gibi farklı aylarda sıcaklık değerleri, tünel (örnek noktas1 10 : $18^{\circ} \mathrm{C}$ ve örnek $11: 18^{\circ} \mathrm{C}$ ve $\left.15.5^{\circ} \mathrm{C}\right)$, galeri çıkışında (örnek noktası: $14,15.5{ }^{\circ} \mathrm{C}$ ) ve Menteş derede (örnek noktas1 3: $17^{\circ} \mathrm{C}$ ) ölçülen değerler hariç, $8^{\circ} \mathrm{C}-13^{\circ} \mathrm{C}$ arasında değişmiştir. Özellikle kaynak sularında ölçülen düşük sıcaklık değerleri suların sı ̆̆ dolaşımlı olduğunu göstermektedir. Ölçülen $\mathrm{pH}$ değerleri ise 6.96 (örnek noktası 16-Elmadağ kaynak) - 8.70 (örnek noktas1 9-Menteş dere) arasında değişmiş olup, değerlerin yaklaşık \%61'i 7.50-8.70 aralığında kalmıştır. $\mathrm{Bu}$ da suların karbonatlı akiferler ile temas halinde olduğunu göstermektedir. Örneklerin Eh değerleri -23 mV (Elmadă̆ kaynak) ile $-96 \mathrm{mV}$ (Menteş dere) arasında değişmiş olup, değerlerin yaklaşık \%87'si $-23 \mathrm{mV}$ ile $-60 \mathrm{mV}$ arasında dağılmıştır. $\mathrm{Bu}$ sonuçta suların oksitleme potansiyeli düşük, sı ğyağışlardan hızla etkilenen-genç sular olduğunu göstermektedir. Menteş deresinde farklı tarihlerde ölçülen $-58 \mathrm{mV},-70 \mathrm{mV}$ ve $-96 \mathrm{mV}$ değerlerinin yeraltı sularının değerlerine benzer çıkması da bu sonucu doğrulamakta olup, bölgede yaygın olan karstik sistemden dolayı yüzey ve yeraltı sularının doğrudan ilişkili olduğunu gösterebilir. Elektriksel iletkenlik (EC) değerleri $16.91 \mu \mathrm{S} / \mathrm{cm}$ $-613 \mu \mathrm{S} / \mathrm{cm}$ gibi geniş bir aralıkta değişmiş olup, yüksek değerler buharlaşma etkisi nedeniyle Attepe gölünü boşaltan kaynağa, düşük değerler ise kuvarsitten boşalan Elmadağ kaynak suyuna aittir. Çizelge 4'den görüleceği gibi, tuzluluk değerleri de, EC değerlerine paralel değişen bir parametre olarak, EC değerleri gibi geniş bir aralıkta değişmiş olup, yüksek ve düşük değerler aynı örnek noktalarında tespit edilmiştir. Her iki parametre ile ilgili olarak, yüksek değerlerin hem göldeki buharlaşmanın etkisi hem de tünel güzergâhları boyunca kayalarda oluşan fiziksel ayrışmanın iyon derişimi üzerindeki arttırıcı etkisiyle açıklanabilir. Benzer şekilde suların sı ̆ dolaşımlı genç sular olmasının bir sonucu olarak, akiferler karbonatlı kayalar olmasına rağmen, toplam alkalinite değerleri de nispeten düşük olup, değişim aralığ $0.4-3.1 \mathrm{mmol} / \mathrm{L}$ olarak belirlenmiştir.

Yerinde ölçümler yapılan su noktalarından seçilen 8 noktada yağışlı ve kurak dönemde örnek alınarak ana iyon, iz element ve izotop analizleri yapılmıştır. Analiz sonuçları değerlendirildiğinde izotop değerleri hariç kurak ve yağışlı dönem arasında dikkat çekici düzenli bir değişim olmadığı; aksine değerlerin birbirine oldukça benzer olduğu görülmüştür. 
Su kaynaklarında Mayıs 2016 döneminde alınarak analiz edilen örneklerin analiz sonuçları Çizelge 5'de verilmiştir. Suların iyon denge hata aralığının -\%0.205 ila \% -0.478 arasında değiştiği hesaplanmış olup, değişim aralığ analizlerin doğru olduğunu göstermektedir. Yapılan değerlendirmeler sonucunda hem yüzey sularında hem de yeraltı sularında ana anyonunun $\mathrm{HCO} 3-$, ana katyonunun ise $\mathrm{Ca}+2$ olduğu; bunun sonucu olarak suların karbonat sertliği \%50'den fazla olan $\mathrm{Ca}$ oranı yüksek $\mathrm{Ca}-\mathrm{Mg}-\mathrm{Na}+\mathrm{K}-\mathrm{HCO} 3$ tipi sular sınıfinda yer aldığı ortaya konmuştur. $\mathrm{Bu}$ sonuç Demiroğlu ve Örgün (2016)'de açıklanan sonucu doğrulamaktadır.

Ortaya çıkan tüm sonuçlar Menteş havzasında ana akiferin dolomit-dolomitik kireçtaşları ve kristalize kireçtaşı bileşimli olduğu şeklindeki arazi gözlemlerini desteklemiştir. Şekil 5' de verilen yarı- logaritmik Schoeller diyagramında ortaya çıkan dağılım da kısmen yüksek sülfat ve magnezyum içeriği ile farklılık gösteren Attepe göl suyu (No: 9) hariç, suların aynı fasiyeste yer aldığını ve akiferin dolomitdolomitik kireçtaşları ve kristalize kireçtaşı bileşiminde olduğunu ortaya koymuştur.

Öte yandan Şekil 5'te açıkça görüldüğ̈̈ gibi 3 no'lu dere suyu örneğinin iyon eğilimi 5, 12, 14,15 nolu yeraltı sularının eğilimleriyle bire bir örtüşmüştür. 6 ve 16 no'lu örnekler ise yüksek kotlardan boşalan dolaşım süresi çok kısa yağmur suyunu temsil edecek özellikteki yeraltı suyu örnekleri olduğunu belirtmek gerekir. Bu da daha önce belirtildiği gibi havzada önemli miktarda dere suyunun yeraltı suyuna karıştığ 1 ve yeraltı suyunu beslediği sonucu ile örtüşmektedir.

Kimyasal analizler için alınan sekiz örnek bir paket program kapsaminda 66 element açısından ICP-MS yöntemiyle analiz edilmiştir. Bu elementlerden Ag, As, $\mathrm{Au}, \mathrm{Be}, \mathrm{Bi}, \mathrm{Cd}, \mathrm{Ce}, \mathrm{Cs}$, Dy, Er, Eu, Ga, Ge, Fe, Hf, Hg, Ho, In, Lu, Mo, Nb, Ni, Pd, Pr, Ru, Sn, Sm, Ta, Tb,Ti, Th, Tl, Tm, Yb, V, W, Zr, Ce, Gd, La, Pt, Re, Rh, Sc, Se, Te ve $Y$ değerleri dedeksiyon limiti altında ve/veya ihmal edilecek derecede düşük çıkmıştır. $\mathrm{Bu}$ elementler dışında kalan diğer elementlerin sonuçları Çizelge 5'de verilmiştir. Ülkemizin Divriği-Hekimhan Havzası'ndan sonra ikinci büyük demir havzası olan Mansurlu bölgesinde yer alan Attepe-Elmadağ-Menteş-Karaçat demir sahalarında üretilen başlıca cevher mineralleri Hematit, Götit, Limonit ve az miktarda Siderittir. Sahanın demir cevheri üreten bir maden sahası olması nedeniyle, element dağılımları hakkında fikir vermesi bakımından, dedeksiyon limiti altında kalmasına rağmen $\mathrm{Fe}, \mathrm{Cr}$, $\mathrm{Co}$ ve As değerleri de ilgili çizelgede verilmiştir. Termodinamik veriler $\mathrm{Fe}+3$ oksitlerin genellikle çok düşük çözünürlüğe sahip olduğunu ve $\mathrm{pH}>6$ şartlarında çözünürlügün daha da düştügünü ortaya koymuştur (Schwertmann, 1991). Sahada işletilen cevher mineralleri Hematit ve Götit olup, her iki mineralin de çözünürlüğü son derece düşüktür. Yanı sıra oksitlenme potansiyeli yüksek olan pirit minerali sahada ihmal edilebilir miktardadır. Bu iki etkenle birlikte akiferlerin karbonatlı kayaçlardan meydana gelmesi ve suların alkali karakterde olması suların düşük Fe içeriğini açıklayabilir. İlgili çizelgeden görüleceği gibi Menteş dere ve Attepe gölü sularının (3 ve 9 no'lu örnekler) element içerikleri yeraltı sularının değerleriyle hemen hemen aynıdır ve değerler son derece düşüktür. Bu sonuç, bölgedeki maden yataklarının yüzey ve yeraltı sularının fiziksel ve kimyasal özellikleri üzerinde belirlenebilir her hangi bir etki yaratmadığını göstermiştir. 
Demiroğlu, Örgün

Çizelge 4. Su örneklemesi yapılan lokasyonlar ve farklı tarihlerde su noktalarında yerinde yapılan ölçüm sonuçları. 2014 Nisan ve Temmuz verileri Demiroğlu ve Örgün (2016)'dan alınmıştır.

Table 4. Water sampling locations and on-site measurement results at different water points. The data for April and July 2014 were taken from Demiroğlu and Örgün (2016).

\begin{tabular}{|c|c|c|c|c|c|c|c|c|}
\hline No & Lokasyon & Tarih & $\mathbf{T}\left({ }^{\circ} \mathrm{C}\right)$ & pH & $\begin{array}{l}\text { Eh } \\
(\mathrm{mV})\end{array}$ & $\mathrm{EC}(\boldsymbol{\mu S} / \mathrm{cm})$ & $\begin{array}{c}\text { NaCl } \\
\text { (Tuzluluk) } \\
\text { (mg/L) }\end{array}$ & $\begin{array}{c}\text { Toplam } \\
\text { Alkalinite } \\
\text { (mmol/L) }\end{array}$ \\
\hline \multirow[t]{3}{*}{1} & \multirow[t]{3}{*}{ Karaçat (Yertaş) Galerisi } & 01.04 .2014 & 9.3 & 8.16 & -66 & 274 & 128 & - \\
\hline & & 07.07 .2014 & 12.5 & 8.09 & -60 & 238 & 102 & - \\
\hline & & 09.10 .2014 & kuru & & & & & \\
\hline \multirow[t]{2}{*}{10} & \multirow[t]{2}{*}{ Tünel (232.m.) } & 01.04 .2014 & - & 7.98 & -56 & 480 & 278 & - \\
\hline & & 07.07 .2014 & 18 & 7.84 & -57 & 490 & “" & \\
\hline \multirow[t]{5}{*}{11} & \multirow[t]{3}{*}{ Tünel (426. m.) } & 01.04 .2014 & - & 8.48 & -86 & 530 & 241 & - \\
\hline & & 07.07 .2014 & 18 & 7.77 & -50 & 550 & - & - \\
\hline & & 09.10 .2014 & kuru & & & & & - \\
\hline & \multirow[t]{2}{*}{ Tünel (920.m.) } & 07.07 .2014 & 15.5 & 7.26 & - & 173 & - & - \\
\hline & & 09.10 .2014 & 11 & 7.54 & -43 & 253 & 51.40 & - \\
\hline \multirow[t]{3}{*}{3} & \multirow[t]{3}{*}{ Menteş Dere } & 01.04 .2014 & 12 & 8.70 & -96 & 206 & - & - \\
\hline & & 07.07 .2014 & 14 & 7.84 & -58 & 218 & 128 & 2.19 \\
\hline & & 16.05 .2016 & 17 & 7.83 & -70 & 143.5 & 67.7 & 2.4 \\
\hline \multirow[t]{3}{*}{5} & \multirow[t]{3}{*}{ Uyuz pınarı kaynağı } & 07.07 .2014 & 14 & 7,76 & -42 & 194 & 94.8 & 1.95 \\
\hline & & 16.05 .2016 & 13 & 7.51 & -52 & 126.5 & 59.1 & 2.2 \\
\hline & & 06.03 .2016 & 8 & 7,48 & -49 & 131 & 62,1 & 2,7 \\
\hline \multirow[t]{2}{*}{6} & \multirow[t]{2}{*}{ Şantiye kaynak suyu } & 07.07 .2014 & 13 & 7.81 & -55 & 51 & - & 2.38 \\
\hline & & 16.05 .2016 & 9.9 & 7.09 & -33 & 28 & 12.8 & 1.9 \\
\hline \multirow[t]{4}{*}{9} & \multirow{4}{*}{$\begin{array}{l}\text { Attepe gölünü boşaltan } \\
\text { kaynağın suyu }\end{array}$} & 07.07 .2014 & 9.7 & 7.56 & -40 & 613 & 279 & 4.28 \\
\hline & & 05.03 .2016 & 10.5 & 7.21 & -34 & 447 & 208 & 3.4 \\
\hline & & 16.05 .2016 & 12 & 7.60 & -58 & 440 & 211 & 3.1 \\
\hline & & 06.10 .2016 & 10.5 & 7.21 & -34 & 457 & 217 & 3.4 \\
\hline \multirow[t]{2}{*}{12} & \multirow[t]{2}{*}{ Karaköy kaynağ1 } & 07.07 .2014 & 16 & 7.31 & -30 & 204 & - & 2.38 \\
\hline & & 16.05 .2016 & 12.6 & 7.33 & -42 & 149.8 & 70 & 2.9 \\
\hline 13 & Avlağa kaynağ1 & 09.10 .2014 & 13 & 7,42 & -25 & 144 & & \\
\hline \multirow[t]{4}{*}{14} & \multirow[t]{4}{*}{ Drenaj Galerisi çıkışı } & 07.07 .2014 & 15.5 & 7.26 & -26 & 273 & - & 2.57 \\
\hline & & 16.05 .2016 & 12.5 & 7.71 & -59 & 137 & 64 & 2.5 \\
\hline & & 05.03 .2016 & 9.9 & 7.60 & -54 & 163.5 & 77 & 2.4 \\
\hline & & 06.03 .2016 & 9.0 & 7.12 & -47 & 158 & 74.6 & 3.4 \\
\hline \multirow[t]{2}{*}{15} & \multirow[t]{2}{*}{ Şantiye su kuyusu } & 07.07 .2014 & 11 & 7.54 & -43 & 253 & - & 2.57 \\
\hline & & 16.05 .2016 & 13 & 7.63 & -52 & 155.8 & 73.8 & 2.8 \\
\hline \multirow[t]{2}{*}{16} & \multirow[t]{2}{*}{ Elmadağ kaynak } & 16.05 .2016 & 11 & 6.96 & -27 & 16.91 & 7.77 & 0.5 \\
\hline & & 05.03 .2016 & 8.4 & 7.01 & -23 & 19.96 & 9.25 & 0.4 \\
\hline
\end{tabular}




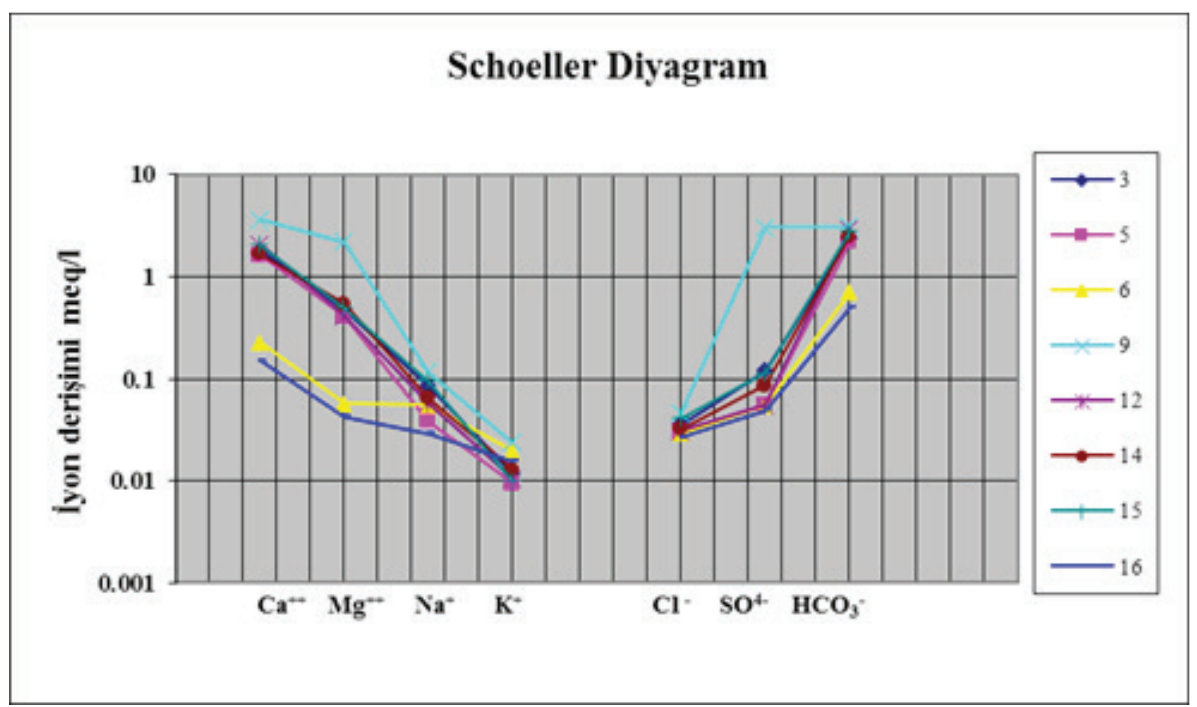

Şekil 5. Yar1- logaritmik Schoeller diyagramı.

Figure 5. Semi-logartihmic Schoeller diagram.

İzotop analizleri ile havzada yeraltı suyu dolaşım süresinin belirlenmesinin yanı sıra, Attepe göl ile Karaçat yeraltı maden galerisinde üretim sırasında boşalan ve kontrol edilemeyen su arasında bağlantı olup olmadığı araştırılmıştır. $\mathrm{Bu}$ amaçla Attepe gölünden boşalan kaynaktan (örnek no:9), Uyuz pınarı kaynağından (örnek no:5), Elmadă̆ kaynağından (örnek no:16), Şantiye kuyu suyundan (örnek no:15), Drenaj galerisi çıkışından (örnek no:14) ve Karaçat galerisinden boşalan yeraltı suyundan (örnek no:1) örnekler alınmıştır. $\mathrm{Bu}$ su noktalarından farklı tarihlerde alınan örneklerin sonuçları Çizelge 6'da verilmiştir.

Çizelgede verilen 1 no'lu örneğe ait sonuçlar ve 9 no'lu örneğe ait 2014 yılı sonuçları Demiroğlu ve Örgün (2016)'dan alınmıştır. İlgili çizelgeden Attepe göl suyuna ait değerlerin, diğer örneklerin değerinden beklendiği üzere farklı olduğu görülecektir. Dönem bazında diğer yeraltı sularının sonuçlarındaki kısmi benzerlik ve/veya yakın değerler ise kuvarsit ve şistlerle sinırlanarak birbirinden ayrılan akiferlerin, yine de zayıf iletimliliği olan faylarla birbirine bağlandığını gösterebilir. Öte yandan, Attepe Göl suyu ile karışımı mümkün olmayan ve alandaki akım memba tarafı yeraltı suyunu temsil eden Uyuzpınarı değerleri dikkate alındığında, Uyuzpınarı ile benzer değerlere sahip drenaj galerisinden boşalan yeraltı sularına ait değerler, buharlaşmanın etkisiyle $\delta^{18} \mathrm{O}$ ve $\mathrm{D} \quad\left(\delta^{2} \mathrm{H}\right)$ değerleri yüksek, Döteryum fazlası düşük olan Attepe Gölü suyunun, galeriden boşalan yeraltı suyu ile bağlantısının olmadığını (sülfat ve klor konsantrasyonlarının da işaret ettiği üzere) göstermekte ve Demiroğlu ve Örgün (2016)'nun bu husustaki değerlendirmelerini yeni veriler ile teyit etmektedir. Ancak, tüm örneklerin $\delta^{18} \mathrm{O}$ ve $\mathrm{D}\left(\delta^{2} \mathrm{H}\right)$ değeri, meteorik su doğruları üzerinde ve arasında dağılmış ve bu sonuç Demiroğlu ve Örgün (2016)' da belirtildiği gibi suların meteorik kökenli olduklarını ortaya koymuştur. Sahadan 2015-2017 y1llarında farklı aylarda alınan yeraltı suyu örneklerinin $2.44 \pm 0.45-4.89 \pm 0.76$ arasında değişen Trityum değerleri, Demiroğlu ve Örgün (2016)'ün ortaya koyduğu sonuçlarla uyumlu olarak, suların akiferden geçiş süresi kısa ve en fazla 5-10 yıllık sular olduğunu ortaya koymuştur. 
Demiroğlu, Örgün

Çizelge 5. Mayıs 2016 döneminde alınan su örneklerinin katyon, anyon (Ca - F, mg/L) ve iz element (Al - Zn, $\mu \mathrm{g} / \mathrm{L})$ analiz sonuçları.

Table 5. Cation, Anion (Ca-F, $\mathrm{mg} / \mathrm{L})$ and trace element $(\mathrm{Al}-\mathrm{Zn}, \mu \mathrm{g} / \mathrm{L})$ analysis results of the water samples taken in May 2016.

\begin{tabular}{|c|c|c|c|c|c|c|c|c|}
\hline Örnek no & 3 & 5 & 6 & 9 & 12 & 14 & 15 & 16 \\
\hline $\mathrm{Ca}$ & 36.48 & 32.51 & 4.60 & 72.61 & 41.79 & 33.47 & 40.98 & 3.02 \\
\hline Mg & 5.7 & 5.01 & 0.70 & 26.83 & 4.96 & 6.62 & 6.00 & 0.52 \\
\hline $\mathrm{Na}$ & 1.95 & 0.88 & 1.28 & 2.70 & 1.32 & 1.48 & 2.19 & 0.67 \\
\hline K & 0.46 & 0.37 & 0.77 & 0.92 & 0.41 & 0.51 & 0.39 & 0.61 \\
\hline $\mathrm{HCO}_{3}$ & 146 & 134 & 43 & 189 & 177 & 153 & 171 & 31 \\
\hline $\mathrm{SO}_{4}$ & 5.82 & 2.67 & 2.68 & 146.3 & 2.64 & 4.17 & 5.52 & 2.35 \\
\hline $\mathrm{Cl}$ & 1.27 & 1.07 & 1.02 & 1.63 & 1.07 & 1.14 & 1.46 & 0.93 \\
\hline $\mathrm{NO}_{2}$ & 0.016 & 0.064 & 0.007 & 0.129 & 0.036 & 0.156 & 0.01 & 0.00 \\
\hline $\mathrm{NO}_{3}$ & 2.51 & 4.50 & 2.13 & 14.18 & 3.19 & 5.12 & 8.19 & 1.47 \\
\hline $\mathbf{F}$ & 0.077 & 0.026 & 0.028 & 0.049 & 0.037 & 0.041 & 0.048 & 0.016 \\
\hline Al & 1.00 & 1.00 & 3.00 & 3.00 & 2.00 & 6.00 & 3.00 & 5.00 \\
\hline As & $<0.05$ & $<0.05$ & $<0.05$ & $<0.05$ & $<0.05$ & $<0.05$ & $<0.05$ & $<0.05$ \\
\hline B & $<5$ & $<5$ & $<5$ & 6 & $<5$ & $<5$ & 7 & $<5$ \\
\hline $\mathbf{B a}$ & 140.8 & 94.9 & 7.85 & 31.4 & 127.9 & 101.2 & 152.6 & 8.32 \\
\hline $\mathrm{Br}$ & 6 & 8 & 6 & 15 & 10 & 6 & 11 & 7 \\
\hline Co & $<0.02$ & $<0.02$ & 0.02 & 0.04 & $<0.02$ & $<0.02$ & $<0.02$ & $<0.02$ \\
\hline $\mathrm{Cr}$ & $<0.05$ & $<0.05$ & $<0.05$ & $<0.05$ & $<0.05$ & $<0.05$ & $<0.05$ & $<0.05$ \\
\hline $\mathbf{C u}$ & 0.3 & 0.2 & 0.2 & 1.8 & 0.3 & 0.2 & 0.4 & 0.2 \\
\hline $\mathrm{Fe}$ & $<10$ & $<10$ & $<10$ & $<10$ & $<10$ & $<10$ & $<10$ & $<10$ \\
\hline $\mathbf{L i}$ & 0.8 & 0.2 & 0.2 & 1.5 & 0.3 & 0.7 & 0.8 & 0.1 \\
\hline Mn & 1.58 & 0.5 & 0.39 & 4.9 & 1.47 & 0.63 & 2.39 & 0.59 \\
\hline $\mathbf{N i}$ & $<0.2$ & $<0.2$ & $<0.2$ & 0.4 & $<0.2$ & $<0.2$ & 0.6 & $<0.2$ \\
\hline $\mathbf{P}$ & 18 & 19 & 37 & 13 & 25 & 16 & 13 & 80 \\
\hline $\mathbf{P b}$ & $<0.1$ & $<0.1$ & $<0.1$ & 0.3 & 0.2 & $<0.1$ & 0.1 & 0.1 \\
\hline $\mathbf{R b}$ & 0.18 & 0.23 & 0.08 & 0.71 & 0.22 & 0.43 & 0.30 & 0.12 \\
\hline Sb & 0.06 & $<0.05$ & $<0.05$ & 0.88 & $<0.05$ & $<0.05$ & $<0.05$ & $<0.05$ \\
\hline $\mathbf{S i}$ & 3640 & 2717 & 3101 & 3199 & 2999 & 3196 & 3906 & 2766 \\
\hline $\mathrm{Sr}$ & 56.04 & 32.45 & 15.51 & 98.45 & 43.64 & 53.93 & 64.21 & 13.28 \\
\hline $\mathbf{U}$ & 0.22 & 0.21 & $<0.02$ & 4.30 & 0.21 & 0.22 & 0.16 & $<0.02$ \\
\hline $\mathrm{Zn}$ & 3.5 & 0.5 & 0.8 & 2.4 & 0.9 & 0.8 & 3.0 & 1.3 \\
\hline
\end{tabular}


Çizelge 6. Suların izotop analiz sonuçları.

Table 6. Isotope analysis results of the water samples.

\begin{tabular}{lllllll}
\hline Örnek No & Örnek yeri & Tarih* & $\boldsymbol{\delta}^{\mathbf{1 8}} \mathbf{O}$ & $\mathbf{D}\left(\boldsymbol{\delta}^{\mathbf{2}} \mathbf{H}\right)$ & $\mathbf{D F} \mathbf{F}^{* *}$ & $\mathbf{T}$ \\
\hline $\mathbf{1}$ & Karaçat galerisi & 01.04 .2014 & -10.93 & -64.18 & 23.26 & $5.68 \pm 0.49$ \\
\hline $\mathbf{1}$ & Karaçat galerisi & 09.10 .2014 & -10.07 & -63.23 & 17.33 & $<5$ \\
\hline $\mathbf{6}$ & Şantiye ezik zon & 21.07 .2015 & -11.18 & -63.23 & 23.21 & $4.58 \pm 0.76$ \\
\hline $\mathbf{5}$ & Uyuzpınarı & 03.11 .2015 & & & - & $4.53 \pm 0.72$ \\
\hline $\mathbf{5}$ & Uyuzpınarı & 25.11 .2016 & $-10.27 \pm 0.12$ & $-61.59 \pm 0.89$ & 20.57 & $3.5 \pm 0.88$ \\
\hline $\mathbf{5}$ & Uyuzpınarı & 02.09 .2017 & $-9.84 \pm 0.09$ & $-62.41 \pm 0.16$ & 16.31 & - \\
\hline $\mathbf{9}$ & Attepe gölü & 01.04 .2014 & $-9.25 \pm 0.08$ & -62.10 & 11.9 & $6.75 \pm 0.50$ \\
\hline $\mathbf{9}$ & Attepe gölü & 09.10 .2014 & $-8.27 \pm 0.07$ & -54.58 & 11.58 & $>6$ \\
\hline $\mathbf{9}$ & Attepe gölü & 19.06 .2015 & - & - & - & $4.34 \pm 0.35$ \\
\hline $\mathbf{9}$ & Attepe gölü & 20.06 .2015 & - & - & - & $4.53 \pm 0.72$ \\
\hline $\mathbf{9}$ & Attepe gölü & 25.11 .2016 & $-9.14 \pm 0.12$ & $-56.59 \pm 0.89$ & 16.53 & $2.843 \pm 0.88$ \\
\hline $\mathbf{9}$ & Attepe gölü & 02.09 .2017 & $-8.57 \pm 0.06$ & $-59.36 \pm 0.06$ & 9.2 & - \\
\hline $\mathbf{1 4}$ & Drenaj Galerisi & 19.06 .2015 & $-11.07 \pm 0.13$ & -66.66 & 21.9 & $4.2 \pm 0.76$ \\
\hline $\mathbf{1 4}$ & Drenaj Galerisi & 03.11 .2015 & - & - & & $3.45 \pm 0.66$ \\
\hline $\mathbf{1 4}$ & Drenaj Galerisi & 25.11 .2016 & $-10.34 \pm 0.12$ & $-62.58 \pm 0.89$ & 20.14 & $2.44 \pm 0.44$ \\
\hline $\mathbf{1 4}$ & Drenaj Galerisi & 02.09 .2017 & $-9.88 \pm 0.18$ & $-64.52 \pm 0.32$ & 14.52 & $2.44 \pm 0.45$ \\
\hline $\mathbf{1 4}$ & Drenaj Galerisi & & & & & $4.71 \pm 0.74$ \\
\hline $\mathbf{1 5}$ & Şantiye kuyusu & & & & & $4.43 \pm 0.72$ \\
\hline $\mathbf{1 6}$ & Elmadă̆ kaynak & 25.11 .2016 & $-9.73 \pm 0.12$ & $-57,52 \pm 0.89$ & 20.32 & $4.89 \pm 0.76$ \\
\hline $\mathbf{1 6}$ & Elmadağ kaynak & 02.9 .2017 & $-9.15 \pm 0.07$ & $-61.11 \pm 1.01$ & 13.09 & - \\
\hline
\end{tabular}

*:2014 yılına ait veriler Demiroğlu ve Örgün (2016)'dan alınmıştır

**:DF: Döteryum Fazlası

\section{TARTIŞMA VE SONUÇLAR}

Menteş havzasında geniş yüzey alanına sahip karbonatlı kayalar (dolomit-dolomitik kireçtaşları, kristalize kireçtaşları) Üst Kretase' den itibaren maruz kaldıkları tektonik hareketler sonucu aşırı kırıklı-çatlaklı bir yapı kazanmıştır. $\mathrm{Bu}$ yapısal süreksizlikler, karstlaşma süreçleriyle birlikte artarak, karbonatlı kayaçların yeraltı sularının kolayca dolaşıp-depolanabileceği bir yap1 kazanmasını sağlamıştır. Sahanın hidrojeolojik yapısının, uygun iklim koşullarıyla birleşmesi, yani kışların yoğun yağışlı geçmesi, özellikle bölgenin yüksek kesimlerinde yağışın kar şeklinde olması, bölgenin yeraltı ve yüzey suyu potansiyelini artırmıştır. Bölgedeki DSİ ve EİEI'ye ait akım gözlem istasyonlarının verileri kullanılarak, Menteş deresi doğu alt havzası için akarsu ana yatak eğiminin 0.02970.1278 arasında değiştiği hesaplanmış, elde edilen denklemden alt havza çıkışında ortalama debisi $0.474 \mathrm{~m}^{3} / \mathrm{sn}$ (yaklaşık $500 \mathrm{~L} / \mathrm{sn}$ ) olarak bulunmuştur.

Menteş deresi yüzeysel ve yüzey alt1 akışının karstik boşluklar ve faylarla yeraltı suyuna doğrudan eklendiği dere üzerinde yapılan debi ölçümleriyle tespit edilmiş olup boya 
Demiroğlu, Örgün

deneyleriyle doğrulanması önerilmiştir. Yı11k ortalama $500 \mathrm{~L} / \mathrm{sn}$ yüzey suyunun 400-450 L/ sn kadar miktarının yeraltı suyuna intikal ettiği anlaşılmıştır. Buna göre dere suyundan yeraltı suyuna olan kayıp ya da katk1 \%90 civarındadır.

Arazi gözlemleri, yapılan ölçümler ve testler, yeraltı sularının kireçtaşı ve dolomitler içinde tamamen doygun olmadığı, tercihli akış yolları geliştirdiğini göstermektedir. Basınçlı su testlerinden elde edilen değerler, sahadaki şistler ve kuvarsitlerin geçirimsiz olduğunu, karbonatlı birimlerin kalın olduğu (yaklaşı $350 \mathrm{~m}$ ) kesimlerde tabandaki kristalize dolomitlerin iletimliliğinin zayıf olduğunu (Lugeon değerinin $<1)$ ve gelişmiş karstlaşmanın gözlenmediği zonlarda $(<5$ Lugeon) karstik boşluk ve kanallardan ziyade çatlak ve kırıklı bir yapının egemen olduğunu göstermiştir.

Karaçat sahasında birçok temel sondaj kuyusunda (Örneğin KÇT-154, 157, 178, 190, 191, 195 ve 196) yeraltı suyu seviyesinin ölçülememesi, arazinin bu kesimlerinde beslenim, depolanma ve boşalımın yerel depolanmalı doygun aktif ana kanallar boyunca gerçekleştiğini göstermiştir.

Karaçat yeraltı demir üretim sahasında doğal koşullarda mevcut olan yeraltı suyu dolaşımı ve beslenim-boşalım ilişkisi, kapalı ocak işletmesinden Menteş deresine doğru boşalan drenaj galerisiyle değişmiştir. Havzada karstik akiferde yeraltı suyunun doğal koşullardaki seviye kotu 1500 m civarında iken, $1407 \mathrm{~m}-1418 \mathrm{~m}$ kotlarını birleştiren drenaj galerisinin faaliyete geçmesi ile akiferin doğal koşullardaki boşalım lokasyonunun altında, yeni bir boşalım noktası meydana gelmiştir. Yeni boşalım noktasına göre akiferdeki yeraltı suyu kotu, kurak devrede $1418 \mathrm{~m}-1423 \mathrm{~m}$ civarında oluşmuştur.

Hidrojeokimyasal veriler yeraltı suyuyüzey suyu ilişkisi ve yeraltı suyunun dolaşımı süresinin anlaşılması için faydalı sonuçlar ortaya koymuştur. Seçilen örnek su noktalarında yerinde yapilan T, pH, Eh, EC, Tuzluluk ve toplam alkalinite ölçüm sonuçları ve ana ve iz element analiz sonuçları, Demiroğlu ve Örgün (2016)'nün de belirttiği üzere, Menteş deresi suyunun yeraltı sularına çok benzer özelliklere sahip olduğunu ortaya koymuştur (Çizelge 4 ve 5). Attepe gölünü boşaltan kaynakta ölçülen EC değeri ( $613 \mu \mathrm{S} /$ $\mathrm{cm})$ hariç olmak üzere, diğer EC değerlerinin büyük bir kısmının $150 \mu \mathrm{S} / \mathrm{cm}$ değerinin altında kalmış olması, Menteş havzasında yeraltı sularının uzun süredir dolaşımda olmadığını ve akiferleriyle temas süreleri kısa, sığ dolaşımlı genç sular olduğunu ortaya koymuştur. Bu sonuç, suların düşük Trityum değerleri $(2.44 \pm 0.44$ $5.68 \pm 0.49$ ), düşük toplam ana iyon değerleri ve su fasiyeslerini tanımlayan Yarı-logaritmik Scholler diyagraminda 5, 12, 14, 15 no'lu yeraltı sularının eğilimlerinin dere suyunun eğilimi ile bire bir örtüşmesiyle de desteklenmiştir. Bazı örneklerde ortaya çıkan kısmen yüksek $\mathrm{Na}+\mathrm{K}$ değerleri, suların kireçtaşı ve dolomitlerin yanı sira sahada yaygin olarak bulunan volkanik ara katk1lı şistlerle de temas halinde olduğunu göstermiştir.

Oksijen ve hidrojenin izotopları su molekülleri ile birlikte hareket ettikleri için suların kökeni ve yaşlandırılmasının yanı sıra yüzey veyeraltı suları arasındailişki olup olmadığı sorularının cevaplandırılmasında güvenilir veriler sağlar. Çalışma kapsamında Attepe göl ile Karaçatgalerisinden üretim sırasında boşalan aşırı miktardaki su arasında bağlantı olup olmadığı, Karaçat galerisinden, Deşarj galerisi çıkışından ve içme suyu olarak kullanılan üç kaynaktan örneklerin O-18, Döteryum ve Trityum analiz sonuçları değerlendirilerek araştırılmıştır. Farklı tarih ve dönemlerde alınan örneklerin izotop sonuçları incelendiğinde Attepe göl suyuna ait değerlerin diğerlerinden farklı olduğu ortaya 
çıkmıştır. Ancak 2014 yılında yapılan izotop analizleri sonucundaki döteryum fazlası verileri ve trityum verileri, drenaj galerisinin açılması ve Karaçat karst akiferinin drene edilmesinden sonra değişmiştir. Karaçat akiferinde, K-KB yönünde şistlerle sınırlanarak yükselen nispeten diğer sulardan daha yaşı ı (Statik rezervuar) suların boşalmasından sonra ölçülen Trityum değerleri benzer okunmuştur (Karaçat; 4.2 \pm 0.76 , Attepe; 4.34 \pm 0.35 ). Bu durumda, dönem bazında tüm sonuçlardaki kısmi benzerlik ve/veya yakın değerler, yeraltı sularının yüzey suları ile doğrudan ilişkili olmasıyla açıklanabilir. Ancak Demiroğlu ve Örgün (2016) havzanın güneyinde yer alan Attepe gölü ile Karaçat galerisinden boşalan suyun ilişkili olup/ olmadığını inceleyerek, drenaj galerisinin açılmasından önce Karaçat galerisinde biriken sularla, buharlaşmanın etkisiyle Oksijen-18, Döteryumu yüksek, Döteryum fazlası düşük olan Attepe Gölü suyunun bağlantısının olmadığ 1 sonucuna varmıştır. Bölgenin sergilediği jeolojik ve topoğrafik görünüm de bu sonucu desteklemektedir. Ayrıca yukarıdaki bölümlerde ifade edildiği gibi Attepe gölünün doğusunda yer alan kireçtaşlarının, inceleme alanı kuzeydeki kireçtaşları ile bağlantısı, faylanmaların etkisiyle şistler tarafinda kesilmiştir. Sonuç olarak izotop sonuçları Attepe gölü ile Karaçat akiferi arasında üretim sirasında sorun yaratacak bir hidrolik ilişkinin olmadığını işaret etmektedir.

\section{KATKI BELİRTME}

Bu çalışma “ÖZKOYUNCUMADENCİLIK Metalürji İnşaat San. ve Tic. A.Ş’ye ait AttepeElmadağ-Menteş-Karaçat demir sahalarında Yeraltı ve Yüzey suları arasındaki ilişkinin araştırılması" başlıklı projenin verilerinden üretilmiştir. Proje, Özkoyuncu Madencilik Metalürji İnşaat San. ve Tic. A.Ş ile İTÜ Maden
Fakültesi Vakfı İktisadi İşletmesi arasında imzalanan ve "ITÜ-ARI TEKNOKENT" de onaylanmış olan "Yerbilimlerinde Doğal Kaynaklar ve Risklerin Değerlendirilmesi ve Yeni Teknolojilerin Geliştirilmesi Projesi" kapsamında gerçekleştirilmiştir.

$\mathrm{Bu}$ makale de idari ve mali desteklerinden dolayı İ.T.Ü. Maden Fakültesi Vakfı İktisadi İşletmeleri Maden Fakültesi yönetimine, arazi çalışmaları sırasında vermiş olduğu destekten dolayı Özkoyuncu Madencilik Şirketi yönetimine, genel müdür yardımcısı Şefik Akkoyunlu, Jeolojik araştırmalar müdürü, Jeoloji Yüksek Mühendis Hakan Tayyar'a ve diğer çalışanlara teşekkürlerimizi sunarız.

\section{KAYNAKLAR}

Alan, İ., Şahin, Ş., Altun, İ., Bakırhan, B., Balcı, V., Böke, N., Saçlı, L., Pehlivan, Ş., Kop, A., Hanilçi, N., Çelik, Ö.F., 2007. Orta Torosların jeodinamik evrimi, Ereğli (Konya)-Ulukışla (Niğde)-Karsantı (Adana)-37 Namrun (İçel) yöresi. MTA Rap. No: 11006, 245 s., Ankara (yayınlanmamış).

Arda, N., Tiringa, D., Ateş̧̧i, B., Akça, A. ve Tufan, E., 2008. Yahyalı (Kayseri)- Mansurlu (FekeAdana) yöresi demir sahaları maden jeolojisi ara raporu. MTA Rap. No: 11093, 75 s., Ankara (yayınlanmamış).

Arıkan, Y., 1968. Mansurlu (Feke-Yahyal1) demir zuhurları. MTA Derleme No:3992.

Ayhan, A., İplikçi, E., 1978. Adana iline bağlı Kozan Feke Saimbeyli civarının jeolojik etüdü. MTA Derleme No: 6737, Ankara (yayınlanmamış).

Ayhan, A., 1988. 1:100.000 ölçekli açınsama nitelikli Türkiye jeoloji haritaları serisi.

Burgan, H. I., Aksoy, H., 2018. Annual flow duration curve model for ungauged basins. Hydrology Research 49 (5), 1684-1695.

Blumenthall, M. M., 1941. Niğde ve Adana vilayetleri dahilindeki Torosların jeolojisine umumi bir bakış. MTA Derleme No: 6. 
Demiroğlu, Örgün

Dayan, S., 2007. Adana-Mansurlu Attepe civarındaki demir yataklarının jeolojik, petrografik ve yapısal özelliklerinin incelenmesi. A.Ü. Fen Bilimleri Enstitüsü, Yüksek Lisans Tezi 125 s. (yayınlanmamış).

Demiroğlu M., Örgün Y., 2016. Menteş Havzas1 Yeraltısularının Hidrojeokimyasal Özellikleri (Yahyal1- Kayseri). Türkiye Jeoloji Bülteni, 59(3), 275-297.

Eken, E., 2012. Mağarabeli (Mansurlu - Feke havzas1, adana) demir yatağının maden jeolojisi. Ankara Üniversitesi Fen Bilimleri Enstitüsü Yüksek Lisans Tezi, 139 s. Ankara(yayınlanmamış).

Gürkan, A., 1966. Mansurlu-Feke demir zuhurları ön raporu. MTA Maden Etüt Arşiv No:861.

https://gdex.cr.usgs.gov/gdex USGS LP DAACThe Land Processes Distributed Active Archive Center (LP DAAC), Earth Observing System Data and Information System.

Küpeli, Ş., 1991. Attepe (Mansurlu-Feke) Yöresi Demir Yataklarının Jeolojik, Petrografik ve Jenetik İncelemesi. Selçuk Üniv. Fen Bil. Enst., Doktora Tezi, 227 s., Konya (yayınlanmamış).

Küpeli, Ş., 1998. Attepe (Mansurlu-Feke-Adana) yöresi demir yataklarının jeolojisi ve kökeni. C. Ü. Müh. Fak. Derg., Seri A-Yerbilimleri, 15 (1), 101-118.

Lucias, M., 1927. Antitoros silsilesinde, Zamant1 Suyu ile Göksu arasında Faraşa demir madeni zuhurunda yapılan jeolojik taharriyat hakkında rapor. MTA Derleme No: 421, 84s.

Özgül, N., 1971. Orta Torosların kuzey kesiminin yapısal gelişiminde blok hareketlerin önemi. TJK Bülteni, Cilt: 14, 75-87.
Özgül, N., 1976. Torosların bazı temel jeolojik özellikleri. TJK Bülteni, 16, 39-52.

Özgül, N., Kozlu, H., 2002. Kozan-Feke (Doğu Toroslar) yöresinin stratigrafisi ve yapısal konumu ile ilgili bulgular. TPJD Bülteni, 14(1), $1-36$.

Rondot, J., 1956. 1/100000'lik jeoloji 94/1.2.3. paftaları. MTA Derleme No:2519.

Schwertmann, U., 1991. Solubility and dissolution of iron oxides. Plant and Soil 130, 1-25.

Şahin, M., Bakırdağ, L., Adıgüzel, O., 1984. AdanaFeke-Mansurlu-Mağarabeli demir madeni jeoloji ve rezerv raporu. MTA Derleme No:7506.

Şahin, M., Bakırdağ, L., 1985. Kayseri-AdanaYahyalı, Delialiuşağı, Karakızoluğugediği, Mağarabeli (güney bölüm) Hanyeri demir madeni jeoloji ve rezerv raporu. MTA Derleme No: 7635.

Temelsu Mühendislik Limited Şirketi, 1988. Istranca Dereleri, Kıyıköy Bölgesi Yapılabilirlik Raporu.

Tiringa, D., 2009. Kayseri-Yahyal1-Karaköy, Karaçat demir yatağının maden jeolojisi. Ankara Üniversitesi Fen Bilimleri Enstitüsü Yüksek Lisans Tezi, 139 s., Ankara(yayınlanmamış).

Tiringa, D., Ünlü, T., Sayılı, İ. S., 2009. KayseriYahyalı-Karaköy, Karaçat demir yatağının maden jeolojisi. Jeoloji Mühendisliği Dergisi, 33 (1), 1-43. 